\title{
The interesting cross-paths of HIVIAIDS and water in Southern Africa with special reference to South Africa
}

\author{
CL Obi ${ }^{1 *}$, B Onabolu², MNB Momba ${ }^{3}$, JO Igumbor ${ }^{4}$, J Ramalivahna1, PO Bessong1', \\ EJ van Rensburg ${ }^{2}$, M Lukoto ${ }^{4}$, E Green $^{1}$ and TB Mulaudzi ${ }^{5}$ \\ ${ }^{1}$ Department of Microbiology, University of Venda, P/Bag X5050, Thohoyandou 0950, Limpopo Province, South Africa \\ 2 Department of Public Health, University of Venda P/Bag X5050, Thohoyandou 0950, Limpopo Province, South Africa \\ ${ }^{3}$ Department of Statistics, University of Venda P/Bag X5050, Thohoyandou 0950, Limpopo Province. South Africa \\ ${ }^{4}$ Department of Microbiology University of Limpopo, Limpopo Province, South Africa \\ ${ }^{5}$ Department of Water Care, Tshwane University of Technology, Arcadia Campus, Pretoria, South Africa
}

\begin{abstract}
HIV/AIDS and water-borne diseases account for a substantial degree of morbidity and mortality in different age groups across the globe, but their ripple effects are more devastating in developing countries. Estimates of the HIV/AIDS epidemic in South Africa vary but attest to a mature and generalised epidemic. Antenatal sero-prevalence data show a rising epidemic from less than $1 \%$ prevalence among pregnant women attending antenatal clinics in 1990 to over $29.5 \%$ in 2004 . Prevalence is generally higher among females than males, indicating feminisation of the epidemic. Race analyses in 2003 reveal the highest prevalence to be among African (13\%) followed by Whites and Coloureds (6.2\%) and least among Indians (1.6\%).

The epidemic which has left a wave of orphans, child-headed households and its attendant ripple effects on household structures, demography, economy and education is characterised by a 'pigeon-hole' of several opportunistic infections.

In rural areas, devoid of electricity and potable water, the impact is more profound because of the role of water in cooking, drinking, consumption of anti-retrovirals and in the preparation of milk supplements for infants.

People with compromised immune systems are more prone to several diseases than individuals whose immune systems are not compromised by HIV/AIDS. HIV/AIDS patients therefore have greater requirements for potable water than uninfected individuals. Improving water quality will lead to a decline in child and adult mortality as well as diarrhoeal diseases in people living with HIV/AIDS.

One of the hallmarks of HIV/AIDS is diarrhoea and about $90 \%$ of HIV/AIDS patients in Africa suffer from chronic diarrhoea, an easily recognisable clinical manifestation of water-borne infections. Other linkages between HIV/AIDS and water are breast feeding; unsafe water used in infant formula preparation which increases the risk of diarrhoeal diseases and deaths in infants; anti-retroviral treatment, as safe water is needed during anti-retroviral treatment or treatment for opportunistic infections in HIV.

In addition to providing safe water, supply points and latrines should be close to points of use as this will reduce the long distances that care givers and HIV/AIDS patients undertake to fetch water and appropriate water system design is required.

Added to the above-mentioned are poverty alleviation aspects; poverty enhances vulnerability to HIV infection and AIDS exacerbates poverty.

Secured access to sufficient safe water and sanitation is also a human rights issue, just as stigmatisation of HIV/AIDS has made the disease a human rights issue.

The cross-paths between HIV/AIDS and water have long-term implications for effective water resource management and the provision of wholesome water to communities. Such implications include faltering payment for water supply because HIV and AIDS are financially dis-empowering, erosion of social capital and waning productivity.

Mainstreaming of HIV/AIDS in the water sector is of utmost importance, including development of work-place policies, adaptation and reorganisation of workload, development of strategies for reserve staff, adjustment of performance appraisal systems, pro-poor financing with a focus on water for health and economic benefit and integration of HIV and AIDS into training activities.
\end{abstract}

Keywords: HIV and AIDS, water, linkages, diarrhoea, poverty, sanitation, stigmatisation, human rights

\section{Introduction}

\section{General considerations}

The linkage between HIV/AIDS and water may appear superficial but is indeed an in-depth association which reflects the ripple effects of the scourge of HIV and AIDS on society and the undisputed implications for the provision of water and water resource management. Water resource management and water

\footnotetext{
* To whom all correspondence should be addressed.

III +27 15962 8186; fax: +27 824227280 ;

e-mail: C355251@yahoo.com

Received 24 November 2005; accepted in revised form 20 April 2006.
}

supplies to communities operate within the context of a mature and generalised HIV and AIDS epidemic. World-wide, HIV/ AIDS and water-borne diseases account for a substantial degree of morbidity and mortality in different age groups. Incontrovertibly, water supply to communities in South Africa must take into account the HIV and AIDS epidemic in their design and operations. However, the interaction between HIV/AIDS and water has received only cursory attention in South Africa. In trying to unravel the intricate linkages between HIV/AIDS and water, this paper first documents issues around HIV and AIDS, followed by matters of safe water supply. Thereafter, the various perspectives on the linkages and the importance of HIV and AIDS on the demand for water and sanitation services are presented. 


\begin{tabular}{|c|c|c|c|c|c|c|c|}
\hline \multicolumn{8}{|c|}{$\begin{array}{c}\text { TABLE } 1 \\
\text { Demographic Details and HDI Ranking for SADC Countries, } 2000\end{array}$} \\
\hline \multirow{2}{*}{$\begin{array}{l}\text { SADC } \\
\text { Country }\end{array}$} & \multirow{2}{*}{$\begin{array}{c}\text { Population } \\
\text { in } 2000 \\
\text { (millions) }\end{array}$} & \multirow{2}{*}{$\begin{array}{l}\text { Per capita } \\
\text { GDP in } 1999 \\
\text { (US } \$ / p \cdot y e a r)\end{array}$} & \multirow{2}{*}{$\begin{array}{l}\text { HIVIAIDS } \\
\text { incidence } \\
(\%)\end{array}$} & \multicolumn{2}{|c|}{1995} & \multicolumn{2}{|l|}{$1999-2000$} \\
\hline & & & & $\begin{array}{l}\text { Life expectancy } \\
(y r)\end{array}$ & $\begin{array}{c}\mathrm{HDI} \\
\text { ranking }\end{array}$ & $\begin{array}{l}\text { Life expectancy } \\
(y r)\end{array}$ & $\begin{array}{c}\text { HDI } \\
\text { ranking }\end{array}$ \\
\hline Angola & 12.903 & 336 & $2.8^{* *}$ & 50 & 157 & 47 & 160 \\
\hline Botswana & 1.639 & 2904 & 35.8 & 60 & 71 & 39 & 122 \\
\hline DRC & 52.046 & 110 & $5.1^{* *}$ & 53 & 142 & 48 & 149 \\
\hline Lesotho & 2.156 & 502 & 23.6 & 58 & 137 & 46 & 142 \\
\hline Malawi & 10.778 & 132 & 16.0 & 46 & 157 & 39 & 159 \\
\hline Mozambique & 19.980 & 92 & 13.2 & 52 & 166 & 43 & 169 \\
\hline Namibia & 1.739 & 1969 & 20.0 & 56 & 116 & 50 & 115 \\
\hline South Africa & 43.265 & 3281 & 22.6 & 60 & 100 & 48 & 101 \\
\hline Swaziland & 0.928 & 1255 & 25.3 & 58 & 110 & 46 & 114 \\
\hline Tanzania & 33.744 & 124 & 8.1 & 50 & 149 & 45 & 156 \\
\hline Zambia & 9.191 & 431 & 20.0 & 49 & 136 & 39 & 151 \\
\hline Zimbabwe & 13.109 & 579 & 25.1 & 50 & 124 & 40 & 151 \\
\hline
\end{tabular}

** Unreliable data due to civil wars in these countries

Sources: World Bank (1998); CIA (2000); SADC (2000); UNAIDS (2000) and Whiteside and Sunter (2000).

\section{HIV and AIDS component}

\section{Regional and country HIV and AIDS profile}

Human Immunodeficiency Virus (HIV), the causative agent of Acquired Immunodeficiency Syndrome (AIDS), first reported in San Francisco, USA, in previously well individuals with impaired immune function as evidenced by depletion of CD4 T helper lymphocyte, has emerged as the most significant infectious pathogen that is advancing relentlessly into the current century (UNAIDS, 2000).

In countries the world over, HIV/AIDS is manifesting as an epidemic of unprecedented magnitude (Abdool Karim, 2000; Piot, 2003). A plethora of epidemiological indicators point to the current and rising impact of the epidemic on individuals, families and societies (UNAIDS, 2003). Global aggregates of HIV/AIDS occurrence show that over 60 million people have lived with HIV/AIDS since the beginning of the epidemic; over 20 million of these have already died from AIDS (UNAIDS, 2004 ).

When disaggregated geographically, the HIV/AIDS pandemic shows widespread but uneven distribution in countries world-wide. Countries of sub-Saharan Africa are known to be most severely affected being host to 26.6 million infections (UNAIDS, 2003). The recent UNAIDS report aptly points out that 'Southern Africa is home of about $30 \%$ of people living with HIV/AIDS world-wide' even though it represents less than $2 \%$ of the world's population (UNAIDS, 2003).

Overwhelming evidence indicates that the current trend in Southern Africa will have a marked impact on the future of infants, children, maternal mortalities, life expectancy and economic growth in the area (World Bank, 2001). It has been reported that in 8 out of 12 countries in the Southern African Development Community (SADC) at least $15 \%$ of all adults are infected (Karim, 2002; UNAIDS, 2000; Ashton and Ramasha, 2002). In some of these countries, infection rates among adults range between $25 \%$ and $30 \%$ and this has been attributed to the system of migrant labour, cross-border transportation and trade (Lurie, 2000).

The impact of HIV and AIDS permeates all boundaries and has kept the SADC economies in a parlous state. The extent of the problem of HIV and AIDS in the SADC region is presented in Table 1 and the data indicate that Zambia, Namibia, South Africa, Lesotho, Zimbabwe, Swaziland and Botswana are hardest hit with infection rates of $20.0 \%, 20 \%, 22.6 \%, 23.6 \%$, $25.1 \%, 25.1 \%$ and $35.8 \%$ respectively. Data from the Democratic Republic of Congo (DRC) and Angola are regarded as unreliable, due to the effect of war in undertaking authentic HIV and AIDS surveillance (World Bank, 1998; SADC, 2000; Whiteside and Sunter, 2000). Human Development Index (HDI) ranking which is an index of quality of life, life expectancy and population growth rates have markedly declined over the last 5 to 15 years (World Bank, 1999).

In order to appreciate the extent of the HIV and AIDS pandemic and its ripple effects on different sectors of the economy, it is important to explore the morphology, life cycle, factors affecting disease progression and the genome of the virus.

\section{Morphology and structure of HIV}

The mature HIV virion is an icosahedral particle, roughly spherical at face value, with a diameter of approximately 110 $\mathrm{nm}$. The outer envelope acquired by the virion during budding, is a lipid bi-layer, studded with about 72 spikes. The sticking-out portion of each spike is the major surface glycoprotein of molecular weight 120 kilodaltons (gp120), while the arm of the spike is the trans-membrane glycoprotein with a molecular weight of 41 kilodaltons (gp41) (Fig. 1) (Poignard et al., 2001). The central core contains 4 viral proteins, the capsid protein $\mathrm{p} 24$, the matrix proteins p17, p9 and p7 (Lama and Trono, 1998; Hahn et al., 1999), two copies of the HIV RNA genome to which p9 and 7 are bounded (Jossinet et al., 1999; Theilleux-Delande et al., 2000), and three viral enzymes - reverse transcriptase, integrase and protease, essential for viral replication, are also found in the central core (Jet et al., 2000).

\section{Life cycle of HIV}

The main target cells for HIV infection are human CD4+ T-lymphocytes and macrophages. Tropism for these cells is evident in vitro and in vivo (Marodon et al., 1999; Barkl et al., 2001). Although mature $\mathrm{CD} 8^{+} \mathrm{T}$-cells are not prime targets for HIV infection, evidence suggests that under certain conditions, HIV can infect these cells (Flamand et al., 1998; Lempicki et al., 


\section{Organization of the HIV-1 Virion}

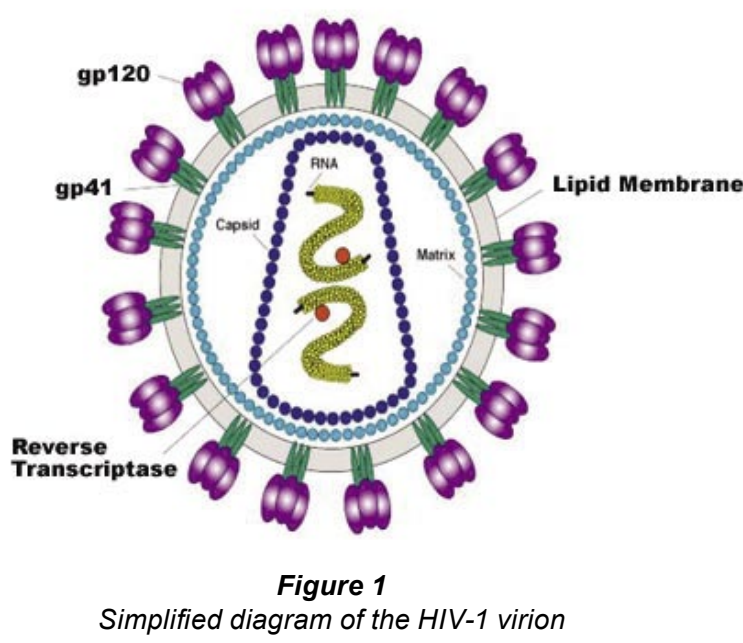

2000). Saha et al. (2001) isolated primary HIV-1 that targets CD8 ${ }^{+}$T-lymphocytes using CD8 as a receptor, and further demonstrated that $\mathrm{CD} 8^{+} \mathrm{T}$-cells in certain patients with AIDS are productively infected. The CD4 glycoprotein on the surface of T-lymphocytes and macrophages serves as a high affinity receptor for HIV. An infection is initiated by binding of the virion envelope gp120 to the CD4 receptor on the host cell (Poignard et al., 2001). Beside CD4, major co-receptors, which are necessary for binding of the virion to susceptible host cells, have been documented. CCR5, a chemotactic cytokine receptor, is a coreceptor for macrophage tropic strains of HIV (also referred to as $\mathrm{R} 5$ viruses), and CXCR4, also a chemokine receptor, is a coreceptor for T-lymphocyte tropic strains of HIV (also referred to as $\mathrm{X} 4$ viruses). These distinctions are not exclusive as strains exhibiting dual tropism have been reported (R5X4 strains) (Braat et al., 1998; Tsherning et al., 1998; Costa et al., 2000; Morris et al., 2001; Nicholson et al., 2001). However, soon after sero-conversion macrophage tropic strains are predominantly found (Schutten et al., 2001). Upon binding of the viral envelope protein to $\mathrm{CD} 4$, the viral envelope undergoes conformational changes that allow binding to the co-receptor. This is followed by a second conformational change of viral envelope protein that triggers the entry of the HIV-1 virion into the target cell (Cullen, 2001). The use of CCR 5 or CXCR4 as co-receptors does not seem to be a universal requirement. Viruses have been isolated that do not need either CCR5 or CXCR4 (Saha et al., 2001a) Following attachment and penetration of the cell membrane by the virion, the viral enzyme, reverse transcriptase (RT) transcribes the viral RNA into DNA. The RNA template is then degraded and a second DNA strand is synthesised. The double stranded DNA copy of the viral sequences (the provirus) is transported to the nucleus and integrates into the host cell DNA. Integration of the provirus is assisted by a virus-specific enzyme, integrase (Bouyac-Bertoia et al., 2001).

The integrated provirus may be transcriptionally inactive and behave like any other silent cellular gene. When the host cell divides, the proviral gene is transmitted to daughter cells as part of the host cell chromosomes. The ability of HIV, like the other retroviruses, to exist in two forms, both as RNA containing virus particles and as host cellular genes, enables them to persist in cells of an infected individual. When the provirus becomes transcriptionally active, the host cellular enzymes (RNA polymerases) carry out transcription of the integrated provirus DNA template and cellular mechanisms also complete RNA processing and transport to ribosomes in the cell cytoplasm. Viral protein synthesis, further processing into viral glycoproteins and transport to the cell membrane - where maturation of viral particles occurs through a budding process - are carried out by the cell's machinery. A virus-specific enzyme, protease, is involved in the cleavage of the large precursor proteins into functional capsid, nucleocapsid, matrix and enzymatic proteins. This cleavage occurs during the formation of the viral particle and is part of the maturation process.

Unintegrated forms of HIV DNA have, however, been demonstrated in dormant T-lymphocytes, both after in vitro infection and in people with asymptomatic HIV infection. For an effective virus infection to occur, HIV DNA has to be integrated into the host cell genome. Furthermore, HIV integration depends on the activation state of the host cell (Barkl et al., 2001). Therefore, mitogenetic agents or other infecting micro-organisms promote viral integration and thereby virus production.

Viral replication ensues in the lymphoid tissues, predominantly in activated CD4 cells but also to some degree in resting CD4 cells (Zhang et al., 1999). The virus subsequently disseminates hematogeneously and vigorous replication occurs in the brain, spleen and gut lymphoid tissue. During this initial viremic phase, the virus is present in the plasma at markedly high levels, usually exceeding 1 million RNA copies/m $\ell$ (Rosenburg et al., 2000).

\section{Establishment of chronic infection}

Following the initial peak viremia levels during acute infection, the plasma viral RNA level decreases dramatically, establishing at an equilibrium level referred to as the 'viral set point' (Lyles et al., 2000). In persons with higher viral load and progressive HIV-1 disease the set point increases with time and with fading immunity. The virus load after acute infection is a strong predictor of the rate of subsequent CD4+ lymphocyte decrease. Viral replication persists once infection is established and this is associated with ongoing destruction of productively infected CD4 cells. The half-life of productively infected lymphocytes is estimated to be $1.5 \mathrm{~d}$. Furthermore, reservoirs of latently infected cells are established in the body, where HIV-1 can remain viable indefinitely, even in the face of highly active anti-retroviral therapy (HAART). This reservoir of HIV-1 exists largely as integrated proviral DNA, and because these memory cells are not expanding, the virus is in a state of replicative quiescence (Bukrinsky et al., 1991). As a result, it is impervious both to immune surveillance and to currently available anti-retroviral therapies, which target the enzymatic antigens of viral replication. This pool is established very early during infection (Schacker et al., 2000).

\section{Factors influencing disease progression}

There is considerable variation in the course of infection among individuals. Observations have been made of infected individuals who have manifested no clinical illness or decrease in CD4 cell counts and in whom viral replication appears to be controlled without anti-retroviral therapy. These individuals have been referred to as 'long-term non-progressors' or 'long-term survivors'. Disease progression seems to be mediated by viral factors, host genetics and host immune reactions to infection. Strains of HIV-1 with reduced virulence have been identified (Deacon et al., 1995). It has also been shown that persons infected with a virus containing deletions in the regions of the nef gene and the long terminal repeat had significantly reduced pathogenic 


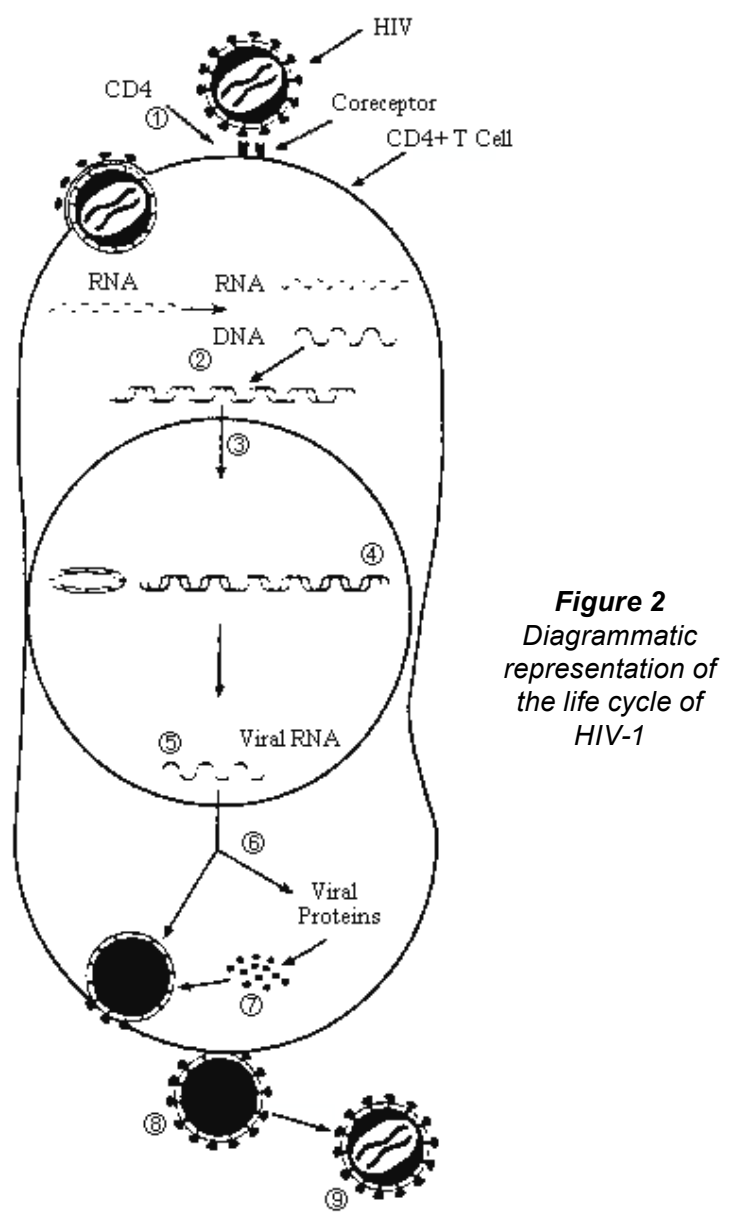

potential (Dyer et al., 1997). Host genetic factors, including coreceptor polymorphisms and human leukocyte antigen (HLA) types, play a role in some cases of apparent resistance to infection and slow progression of disease (Biti et al., 1997; Buchacz et al., 1998; Michael, 1999). Individuals homozygous for a mutated CCR5 gene containing a 32 base pair deletion (CCR5 $\Delta 32)$ possess relative resistance to infection by R 5 strains of HIV-1. This is further evidenced by the fact that reported infection of these individuals has been ascribed to $\mathrm{X} 4$ viruses, which make use of the CXCR5 co-receptor. Individuals who are heterozygous for the CCR5 mutation may also benefit in terms of the rate of HIV-1 disease progression (Michael et al., 1997; Paxton et al., 1998; Walli et al., 1998). In HIV-infected patients, the level of expression of CCR5 is correlated with the virus load, with greater levels of CCR5 expression associated with high HIV RNA levels, independent of T cell activation-induced up-regulation of the co-receptor (Reynes et al., 2000; De Roda-Husman et al., 1999). Another genetic influence on disease progression is provided by specific HLA alleles expressed on the cell surface. These molecules serve to present viral peptides to the immune system for recognition, and certain alleles, such as B27, B51, and B57 are associated with a better clinical outcome (Kaslow et al., 1996; Hendel et al., 1999). On the other hand, alleles such as B35 are associated with a more rapid progression (Harrington et al., 1999), although the precise mechanisms through which these effects are conferred have yet to be defined.

Host immunity also plays a role in the regulation of the rate of HIV-1 disease progression. The rapid decline in peak viremia levels after acute infection suggests that active immune responses might be contributing to the observed containment of replication. In contrast to other viral infections where neu- tralising antibodies that directly neutralise free viruses are the key to immune control, this does not seem to be the case in HIV infection. The fact that peak levels of acute viremia generally decrease by $>100$ fold before neutralising antibody activity is detectable argues against a central role of neutralising antibodies in the initial control of viral replication (Pelligrin et al., 1996). Cytotoxic T lymphocytes (CTL) seem to play a more vital role in the containment of HIV replication and disease progression. While viral proteins are being assembled to form new infectious virions, fragments of these proteins are complexed with HLA Class I molecule and presented to the cell surface. These complexes alert CTLs which produce soluble antiviral chemokines, which reduce the ability of the progeny viruses to infect new cells (Cohen and Walker, 2000). CTLs directed against HIV-1 are commonly detected in HIVinfected individuals early in the course of the disease and this coincides with the decline in the level of viremia (Musey et al., 1997).

\section{HIV genes and gene products}

Similar to all replication-competent viruses, the gag and env genes encode structural proteins and the pol gene encodes enzymatic proteins (Robey et al., 1985). In the transcription and translation of these genes, three classes of messenger RNA (mRNA) size can be distinguished, namely genome length mRNA, singly-spliced mRNAs and multiply-spliced mRNAs. Translation of the genome length mRNA yields a large polyprotein encompassing all gag and pol products. This precursor is cleaved in several steps by the viral protease to give the inner structural components and enzymes of the viral particle. Translation of singly-spliced mRNAs yields the envelope precursor protein gp160, which is cleaved by host cellular enzymes to give the major external envelope glycoprotein gp120 and the trans-membrane protein gp41 (Veronese et al., 1985). Individuals infected with HIV produce antibodies to viral proteins, and the presence of specific antibodies to viral antigens is the basis of the serological diagnosis of HIV infection (Ayouba et al., 2001).

The HIV genome also encodes several regulatory proteins from corresponding genes (Willard-Gallo et al., 2001). The tat and rev proteins are produced from overlapping reading frames by multiply-spliced mRNAs and encode small nuclear proteins that regulate transcription of other HIV genes. HIV1 tat has been shown to be vital for the initiation of transcrition. The vif protein has a role in production of infectious virus (Sova et al., 2001). Vpu, protein of trans-membrane and cytoplasmic domains, has been shown to regulate the processing of gp160 into gp120 and gp41 (Margotti et al., 1998), as well as promoting the release of budding virions from the host cell (Deora and Ratner, 2001). The nef protein assists in viral entry into susceptible cells and hence enhances infectivity (Zhou and Aiken, 2001). However, because of structural differences exhibited by nef genes of various HIV subtypes, there may be other functional consequences with regards to the role of the nef gene in AIDS (Foster et al., 2001). Studies comparing the long-term non-progressors (LTNP) and progressors elucidated the role of the nef product in disease progression. LTNP exhibit a mutation in the nef region compared to the nef region of progressors, indicating the pathogenic role of the nef region (Rhodes et al., 2000). The vpr protein has been documented to demonstrate in vitro both the regulation of productive HIV-1 infection and CD4-mediated T-cell functions (Schaeffer et al., 2001). 


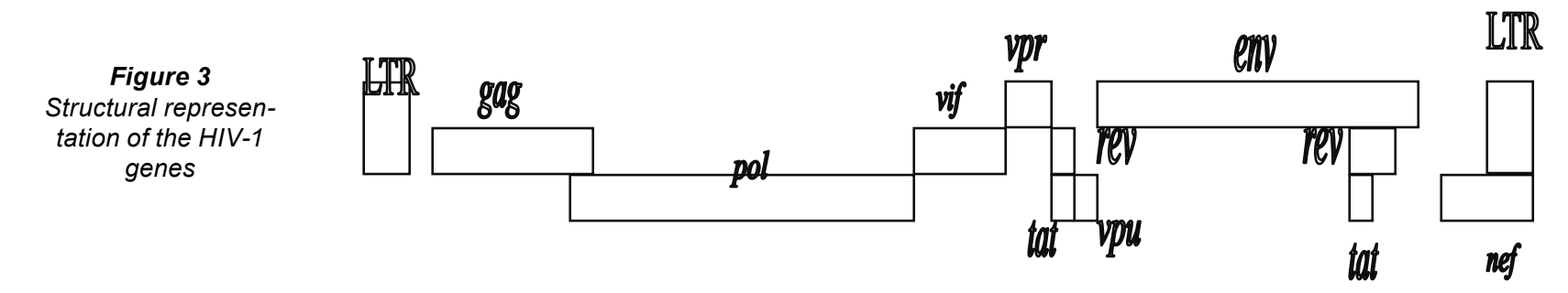

\section{The HIV-1 genome}

The 9-kilobase single-stranded HIV RNA contains the envelope (env) gene, the group associated antigen ( $g a g)$ gene, and the polymerase $(\mathrm{pol})$ gene. These genes are essential for retroviral replication. In addition there are at least 6 other genes that mediate regulatory functions in the life cycle of HIV-1. These include the tat, rev, vif, vpu, nef and vpr genes (Yamada and Iwamoto, 2000; Fackler et al., 2001; Schaeffer et al., 2001).

\section{Genetic variability of HIV-1 and genetic nomenclature}

Based on studies of the genomes HIV-1 isolates from different geographic regions, HIV-1 has been documented to exist as nine different subtypes (A-D, F-H, J and K) within the major Group M. This classification uses phylogenetic and distance analyses of at least three regions of the genome (Roques et al., 1999; Robertson et al., 2000). Formerly designated Subtype E was later shown to be a recombinant between A and E (Gao et al., 1996), though a non-recombinant Subtype E has not been found. Consequently, Subtype E is not recognised as a separate cluster of closely related viruses. In a similar vein, previously tagged Subtype I based on the C3V3 sequences (Kostrikis et al., 1995), has been shown to be a complex recombinant comprising Subtypes A, $G$ and regions that do not fall within any presently known defined subtypes (Nasioulas et al., 1999). These inter-subtype recombinants have been termed circulating recombinant forms (CRFs) since they contribute significantly to the global epidemic. As a result previously known Subtypes E and I are now referred to as CRF01_AE and CRF04_cpx respectively. Various HIV-1 subtypes have been isolated in all indigenous populations of the world with varying degrees of endemicity (Obi et al., 1997 a; b). For example HIV-1 Clade B is mostly found in the Americas, Japan, Australia, the Caribbean and Europe; Clades A and D predominate in sub-Saharan Africa; Clade C in South Africa and India; whereas CRF01_AE is predominant in the Central African Republic, Thailand and in other countries of South-East Asia. Clade F is mainly found in Brazil and Romania with Clades $\mathrm{G}$ and $\mathrm{H}$ present in Russia and Central Africa and CRF04_cpx found in Cyprus. Besides HIV-1 Group M, HIV-1 Groups O and $\mathrm{N}$ have been identified in Cameroon, but are of very low prevalence, although Group $\mathrm{O}$ has been isolated in several European countries and in the USA (Simon et al., 1998; Roques et al., 1999). Other CRFs include CRF02_AG, which represents a recombination between Subtype A and G and circulates in West and Central Africa (Carr et al., 1998; 1999), CRF03_AB which represents a Subtype A/B recombinant form that is found mostly among intravenous drug users in Kaliningrad (Salimen, 1997). In Africa most of the above-mentioned subtypes are found, with Subtypes C and A predominating. HIV-2, a related strain with a $50 \%$ homology with HIV-1 in the envelope gene sequence and comprising Clades A-E, predominantly circulates in West Africa (Hu et. al., 1996). Africa, south of the Sahara represents one of the regions with the highest number of circulating HIV1 clades, and inter-clade recombinants besides HIV-1 Group O and the recently identified HIV-1 Group N (Corbet et al., 2000; Baldrich-Rubio et al., 2001).

Genetic diversity is the hallmark of HIV-1 biology and this creates a major obstacle to diagnostic, drug and vaccine development (Kellam and Larder, 1995; Hu et al., 1996). Several factors are known to contribute to the generation of new variants and influence the speed with which these viruses evolve. One is the error-prone nature of the viral reverse transcriptase (RT), which lacks proof-reading functions and introduces substitutions at a rate of approximately $3 \times 10^{-5}$ nucleotide changes per site per replication cycle. A second factor is the high rate of virus production (up to $10^{10}$ virions/d) and the large numbers of replication cycles (approximately 300/a) that sustain HIV-1 infection in vivo. A third factor is in vivo selection pressure, which, for example, is responsible for the rapid emergence of drug-resistant viral escape mutants. Together, these mechanisms generate viral variants at extraordinary rates and represent a major force driving HIV-1 evolution in infected populations world-wide (Gao et al., 1996, Jet et al., 2000). Recombination may occur in vivo in tissues such as lymph nodes and the spleen, whose viral burden is higher than those of other tissues. The high rate of mutation and the recombination that follows may generate quasi-species, a mixture of closely related viruses, in an infected individual. In a patient infected with multiple HIV-1 strains, recombination can produce more diverse viruses than can mutation (Zhu et al., 1995; Kuwata et al., 1997). Moreover, evidence suggests that recombination among highly divergent HIV-1 strains may occur quite frequently, indicating that this process may also contribute importantly to HIV-1 diversification (Salimen et al., 1997; Takehisa et al., 1999). Genetic diversity is important for the understanding of the HIV epidemic.

\section{HIV epidemiology in South Africa}

Estimates of the HIV/AIDS epidemic in South Africa vary but all attest to a 'mature and generalised epidemic' (Dorrington et al., 2002; USAID, 2003). Variations in estimates may relate to the source of epidemiological data. The main source of information is the series of annual antenatal sero-prevalence surveys conducted by the Department of Health since 1990 (DoH, 2000). Information emanating from this indicates a rising epidemic from less than $1 \%$ prevalence among pregnant women attending antenatal clinics in 1990 to $29.5 \%$ prevalence in 2004 as shown in Fig. 4.

On the basis of antenatal data, several estimates have been made on HIV/AIDS occurrence in South Africa:

- The South African National Department of Health estimates that about 5.7 million South Africans were living with HIV at the end of 2004 (DoH, 2004). This gives a proportion of 1 in 10 South Africans being HIV positive.

- The Medical Research Council (MRC) of South Africa estimates $14.2 \%$ prevalence nationally with wide variations in the provinces; $18.4 \%$ in KwaZulu-Natal to $4.2 \%$ in Western Cape (Dorrington et al., 2002). Incidence nationally was estimated to be $2.1 \%$. 


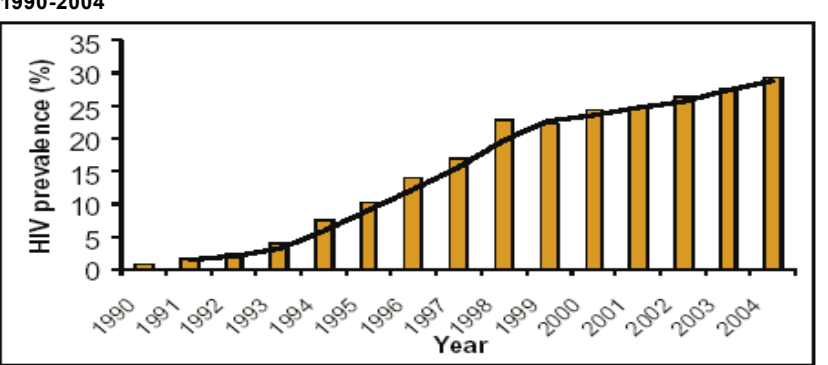

Source: Department of Health, South Africa, 2004

Figure 4

Prevalence of HIV amongst antenatal care attendees in South Africa

Population-based surveys at national and sub-national levels reported slightly lower values compared to those derived from antenatal sero-prevalence data. The study by the HSRC/Nelson Mandela Foundation on national HIV sero-prevalence in 2002 reported a total prevalence of $11.4 \%$ nationally (HSRC, 2002). The study was based on a nationally representative sample of the general South African population and corroborated findings on sub-national samples indicating lower statistics in the general population when compared with extrapolated values from antenatal data (Auvert, 2001; Colvin et al., 1998; MacPhail, 2002). Such observation can be expected for the following reasons: Firstly, antenatal sero-prevalence data are based exclusively on a select group of either currently or recently sexually active women who are pregnant and therefore limited to a single socio-demographic group (HSRC, 2002). Secondly, this group is likely to comprise individuals who do not adopt HIV prevention strategies such as condom use and therefore highlight the situation in a high-risk group (HSRC, 2002). Notwithstanding, both estimates are useful in giving the range of values around which actual statistics may be found.

\section{Prevalence of HIVIAIDS across age groups in South Africa}

There are variations in reported prevalence when the ages of antenatal care attendees are considered. As presented in Fig. 5, prevalence of HIV infection is highest in women between 20 and 29 years of age, lower amongst those less than 20 years old and lowest in those older than 30 years. It is, however, noteworthy that the under-20s are beginning to show a downward trend since 1999 such that by 2001 the prevalence in this group was actually lower than that of the over-30s. This is an important observation as it suggests decreasing occurrence of HIV infection in teenagers indicative of success in HIV preventive measures targeted at this group. This is commensurate with the observed behavioural change in sexual activity in the younger age group (HSRC, 2002; DoH, 2004).

The HSRC determined that the overall prevalence in persons aged between 2 and 14 years was 5.6\%, 15 and 24 years $9.3 \%$ and for those 25 years and older it was $15.5 \%$ (HSRC, 2002). The prevalence among adults of 15 to 45 years was reported to be $15.6 \%$ (HSRC, 2002). Age-specific HIV prevalence rate among antenatal clinic attendees in South Africa for 2004 is presented in Table 2.

Figure 6 shows estimated HIV prevalence in males and females by age groups. It shows that females have higher prevalence at earlier age groups than males. The peak for females is in the 25 to 29 years age group compared to males which peak in the 30 to 34 years age group.

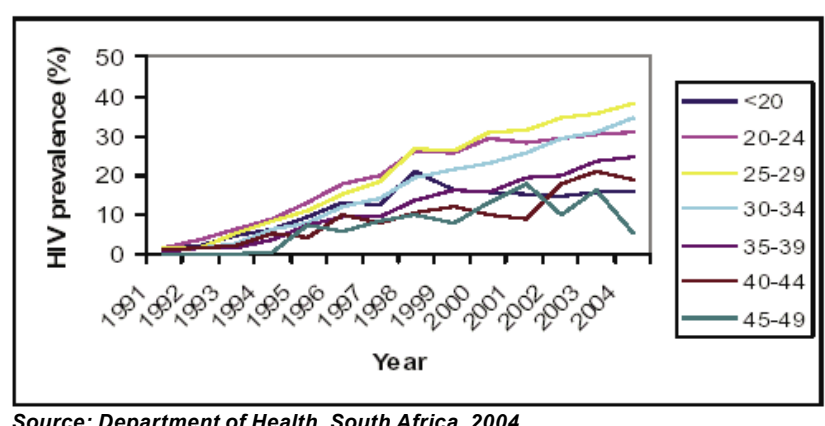

Figure 5

HIV prevalence among pregnant women at antenatal clinics in South Africa, by age group: 1991-2004

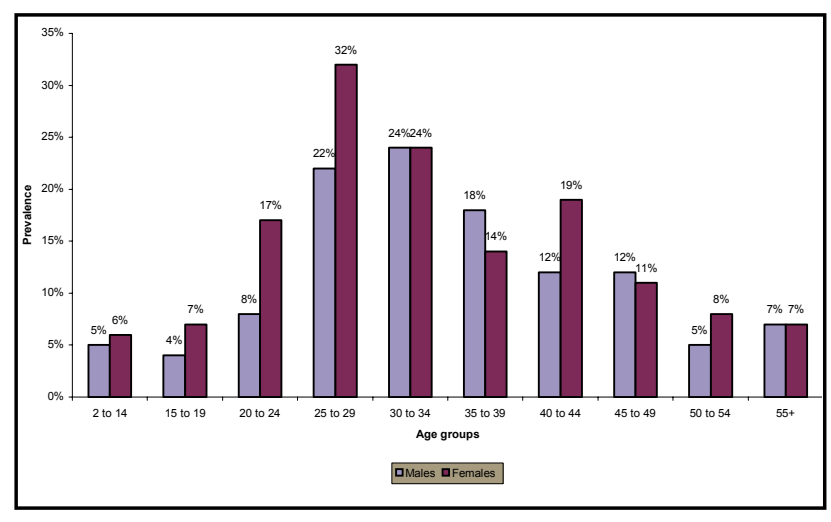

Figure 6

HIV prevalence among males and females by age groups, HSRC 2002

\begin{tabular}{|l|c|c|}
\hline \multicolumn{3}{|c|}{$\begin{array}{c}\text { TABLE 2 } \\
\text { HIV Prevalence by Age Group } \\
\text { among Antenatal Clinic Attendees, } \\
\text { South Africa: } 2004\end{array}$} \\
\hline \multirow{2}{*}{ Age group } & \multicolumn{2}{|c|}{ Prevalence } \\
\cline { 2 - 3 } & Percentage & Age group \\
\hline$<20$ & 16.1 & $14.7-17.5$ \\
\hline $20-24$ & 30.8 & $29.3-32.3$ \\
\hline $25-29$ & 38.5 & $36.8-40.3$ \\
\hline $30-34$ & 34.4 & $32.2-36.6$ \\
\hline $35-39$ & 24.5 & $21.9-27.2$ \\
\hline $40+$ & 17.5 & $14.0-21.0$ \\
\hline
\end{tabular}

\section{Gender prevalence of HIVIAIDS amongst the sexes in South Africa}

'Feminisation' is a known attribute of the HIV/AIDS epidemic globally with higher prevalence reported in females compared to males world-wide (Piot, 2003). The South African HIV/AIDS epidemic is no exception. The overall prevalence in males has been put at $9.5 \%$ compared to that for females which is $12.8 \%$ as shown in Table 3 (HSRC, 2002). This difference is even more pronounced among persons aged between 15 and 49 years where $17.7 \%$ females compared to $12.8 \%$ males are reported to be HIV-positive (HSRC, 2002). A number of explanations have been suggested for this occurrence including increased biological vulnerability in females due to large surface area of their genitalia and other cultural risk factors (Glynn, 2001). 


\begin{tabular}{|l|c|c|}
\hline \multicolumn{3}{|c|}{$\begin{array}{c}\text { TABLE 3 } \\
\text { Overall HIV prevalence by sex } \\
\text { (HSRC, 2002) }\end{array}$} \\
\hline \multirow{2}{*}{ Sex } & \multicolumn{2}{|c|}{ Prevalence } \\
\cline { 2 - 3 } & $\%$ & $\mathbf{9 5 \%}$ Cl \\
\hline Male & $9.5 \%$ & $8.0-11.1$ \\
\hline Female & $12.8 \%$ & $10.9-14.6$ \\
\hline Total & $11.4 \%$ & $10.0-12.7$ \\
\hline
\end{tabular}

\begin{tabular}{|l|c|c|}
\hline \multicolumn{3}{|c|}{$\begin{array}{c}\text { TABLE 4 } \\
\text { Overall HIV prevalence by race } \\
\text { (HSRC, 2002) }\end{array}$} \\
\hline \multirow{2}{*}{ Race } & \multicolumn{2}{|c|}{ Prevalence } \\
\cline { 2 - 3 } & $\%$ & $\mathbf{9 5 \%}$ Cl \\
\hline Africans & $12.9 \%$ & $11.2-14.5$ \\
\hline Coloureds & $6.1 \%$ & $4.5-7.8$ \\
\hline Indians & $1.6 \% \%$ & $0-3.4$ \\
\hline Whites & $6.2 \%$ & $3.1-9.2$ \\
\hline Total & $11.4 \%$ & $10.0-12.7$ \\
\hline
\end{tabular}

The pattern in females is of particular interest and information from the antenatal survey indicates a high prevalence among women aged between 15 to 45 years. The 2001 antenatal data is presented by age groups in Table 2 and corroborates estimates from the HSRC survey.

\section{Prevalence of HIVIAIDS across races in South Africa}

The HSRC survey investigated and reported on the prevalence of HIV/AIDS across races in South Africa (HSRC, 2002). It was found that prevalence was highest in Africans (12.9\%) and lowest in Indians (1.6\%) (HSRC, 2002). Prevalence in Whites $(6.2 \%)$ and Coloureds $(6.1 \%)$ was quite similar to the data shown in Table 4 (HSRC, 2002). This is commensurate with reported deaths due to HIV/AIDS in South Africa.

\section{Prevalence of HIVIAIDS in the provinces in South Africa}

When HIV prevalence is considered among the provinces, stark differentials are noticed in the magnitude of the epidemic in South Africa's nine provinces. At almost 37\%, HIV prevalence among antenatal attendees in KwaZulu-Natal is about three times that of Western Cape (UNAIDS, 2003). This agrees with estimated prevalence for the provinces as determined by the MRC/ASSA (Dorrington et al., 2002). However, as can be observed in Fig. 7, prevalence estimates in the provinces based on the recent population survey by the HSRC show some differences from those calculated using antenatal data. Emerging information suggests that provinces with the highest prevalence are KwaZulu-Natal, Mpumalanga, Free State and Gauteng. North-West and Eastern Cape have intermediate levels whereas Limpopo, Northern Cape and Western Cape have the lowest prevalence.

\section{HIV and migratory labour in South Africa}

The migrant labour system in South Africa has had a contributory impact on the spread of HIV infection in the country (Jochelson et al., 1991; Campbell and Williams, 1999). This is thought to be caused by the removal of spouses (especially men) from their families and regular sex partners while providing a means of disease transmission to those living in rural

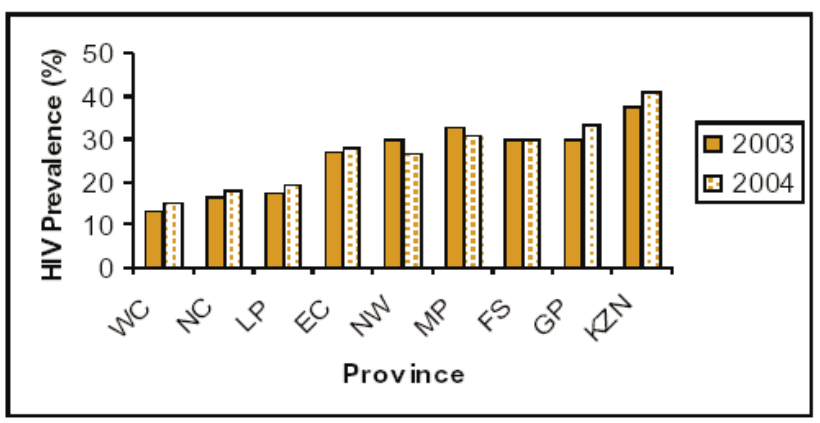

Figure 7

HIV prevalence by province among antenatal clinic attendees, South Africa, 2003-2004

areas when men return to their homes during periods of leave or upon job completion (Campbell and Williams, 1999; Williams et al., 2000). The major occupations that involve migrant labour include mine-workers, truck drivers and cross-border traders.

As can be expected, estimates of HIV/AIDS prevalence in these groups were higher than those of the general population. Within the mining industry for example, it has been estimated that between $20 \%$ and $30 \%$ of workers are HIV positive (Williams et al., 2000). Infection rates of other sexually transmitted diseases are also known to be high, thus predisposing mineworkers to HIV infection (Ballard, 1996). Rates of 4.6\%, 6.7\% and $8.1 \%$ were reported for syphilis, chlamydia and gonorrhoea infections in a sample of 228 mine-workers (Ballard, 1996).

It is probable that the same or similar reasons explain high prevalence among the different occupations involving migratory labour. It will appear that migrant labourers have existed as relevant conduits or human vectors for the propagation of the HIV/AIDS epidemic in the different parts of South Africa.

\section{HIV-type and mode of transmission}

In South Africa, HIV Type 1 (HIV-1) subtype Clade $\mathrm{C}$ has been implicated as the predominant clade (Morris et al., 2000). It is estimated that HIV-1 subtype C accounts for $95 \%$ of HIV infections in South Africa (Bredell et al., 1998; Van Harmelen et al., 1999; DoH, 1999; Morris et al., 2000). The mode of transmission is mostly through heterosexual transmission and to an increasing extent through perinatal transmission (Morris et al., 2000). This is different from the Clade B virus which is predominantly transmitted homosexually but is of less importance in South Africa (IAVI, 1999).

On the basis of the different strains and sub-types of causative agents, South Africa may be viewed as experiencing two independent epidemics of HIV/AIDS (IAVI, 1999). The first epidemic started in the early 1980s among homosexuals and through blood transfusion by infected blood supplies (IAVI, 1999). This led to the first cases of HIV infection in South Africa and was of the Clade B virus. It was, however, not very widespread as there is evidence to show that even by 1985, HIV testing of stored blood samples still had very low prevalence of HIV (IAVI, 1999).

By 1987, however, a second and larger HIV/AIDS epidemic had manifested and rapidly spread through heterosexual intercourse and perinatally to children. Clade $\mathrm{C}$ was the major causative agent.

Absolute rates of transmission through different modes are not known, but transmission through sexual intercourse, both homosexual and heterosexual, is thought to account for at least $95 \%$ of infections. This is followed by perinatal transmission 
and infection through mother's milk accounting for $3.8 \%$ of infections nationally (Dorrington et al., 2002). The remaining percentage is contributed by infection through needle stick injuries, injecting drug users and blood transfusion. These later modes of transmission are therefore of less importance in the HIV/AIDS epidemic in South Africa.

\section{Orphans and vulnerable children in South Africa}

The rate of orphanhood in South Africa is a massive emerging challenge. The premature loss of parent(s) directly translates to the loss of love, care, basic security, guidance and support offered by parents. The absence of parents as agents of socialisation in essence increases a child's risk of developing dysfunctional juvenile and adult behaviours, which in turn manifest in the form of socioeconomic burdens on the society and the state.

Contemporary studies on the prevalence of orphans in South Africa show slight differences in their contextual definition of orphans. The observed differences pertain mostly to the age of the orphan, cause of death of parent(s) and the parent lost. Most studies included children under 15 years old in their definition of orphans. This working definition is consistent with UNAIDS (2002) definition of an AIDS orphan 'as child aged 0-14 years who has lost one or both parents to AIDS'.

Bearing in mind the slight differences in definition of orphans, HSRC (2002) through a population-based survey found that about $13 \%$ of children aged 2 to 14 years had lost either or both of their parents. In addition close to $3 \%$ and $8.4 \%$ of the children aged 2 to 14 years old have lost their mothers and fathers respectively. It is important to note that the findings of the HSRC report were regardless of the cause of death of parent(s).

The MRC/ASSA projection (through AIDS and demographic model) additionally estimated that South Africa had 885980 maternal orphans under 18 years of age as at July 2002 (Dorrington et al., 2002). To allow for comparison between the different information sources, this analysis will partly focus on the MRC/ASSA projections for maternal orphan under 15 years old. In the 2004 projection, AIDS accounted for about half of the total maternal orphans among the under 15-year-olds in all the provinces, except for Limpopo, Northern Cape and Western Cape Provinces, as illustrated in Table 6. A comparison of the 2002 and 2004 projections shows a general increase in the total number of orphans and the proportion of maternal AIDS orphans across the provinces. All the provinces except Limpopo tended to have doubled their number of AIDS maternal orphans between 2002 and 2004. The 2004 projection also estimates that Gauteng and KwaZulu-Natal Provinces would have the highest proportion of maternal orphans and maternal AIDS orphans.

As AIDS orphans increase, non-AIDS orphans are expected to decrease over time (Bradshaw et al., 2002; UNICEF, 2003). This observation was attributed to the expected large numbers of mothers dying of HIV and declining level of fertility (Bradshaw et al., 2002). The gap between the number of AIDS and non-AIDS orphans is expected to widen extensively in the next 11 years as shown in Fig. 8.

The scale and impact of HIV/AIDS in South Africa can be depicted as a succession of four epidemic waves as shown in Fig. 9 (Bradshaw et al., 2002). The $1^{\text {st }}$ wave of new infections (incidence wave) is noted to have already peaked in 1998 at 930000 infections per year (Bradshaw et al., 2002). This is followed by a $2^{\text {nd }}$ wave of number of people infected (prevalence wave) that is expected to peak in 2006 at between 7 and 8 million if there are no changes in behaviour or interventions (Bradshaw et al., 2002). A $3^{\text {rd }}$ wave of AIDS deaths is expected to follow

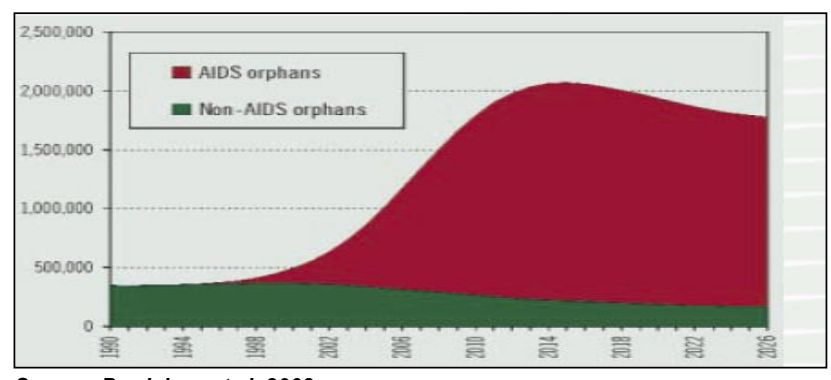

Source: Bradshaw et al, 2002

Figure 8

Estimated number of AIDS and non-AIDS orphans in South Africa

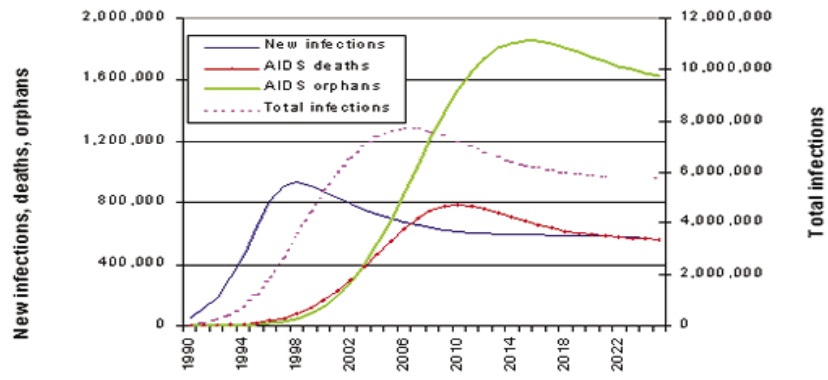

Source: Bradshaw et al, 2002

Figure 9

Waves of HIVIAIDS epidemic and orphanhood in South Africa

the prevalence wave peaking at about 800000 deaths per year in 2010 (Bradshaw et al., 2002). The $4^{\text {th }}$ and final wave of children who will have been orphaned by HIV/AIDS is projected to peak at 1.85 million in around 2015 (Bradshaw et al., 2002). This aptly illustrates that orphaning caused by HIV/AIDS is a long-term chronic problem (Bradshaw et al., 2002; Whiteside, 1999; Smart, 2003).

Provision of anti-retroviral drugs (ARVs) is noted to be the only HIV/AIDS prevention and management intervention with the potential of reducing the projected number of orphans in South Africa (Bradshaw et al., 2002). This is because the ARVs can meaningfully contribute to prolonging the life of infected parents to a point where their children can hopefully be self-sustaining.

HIV/AIDS prevention and management intervention such as behavioural change, condom promotion and AIDS awareness programmes were noted to have a negligible short-term effect on the number of orphans (Bradshaw et al., 2002). These measures may, however, reduce the anticipated number of orphans by about $10 \%$ in 2015 .

- To respond to the growing number of orphans and vulnerable children, Bradshaw et al. (2002) have suggested the following measures: Protecting orphans and vulnerable children through community structures; placing adults in homes of orphans; and creating cluster families

- Creating an enabling environment by expanding state support for children; promoting community based systems; and making ARV freely available.

\section{National response to the HIV and AIDS epidemic in South Africa}

Until recently, the primary activities of the South African Government in addressing the HIV/AIDS epidemic have focused 
on prevention (Dorrington et al., 2002; HSRC, 2002; USAID, 2003). These have included measures geared at 'promoting safe and healthy sexual behaviour, providing voluntary counselling and testing as well as distribution of condoms freely to the population' (HSRC, 2002). In this respect, the National Department of Health has made great strides. In 2002, for example, over 356 million condoms were procured and distributed making South Africa one of the few countries world-wide with high government commitment to condom use in HIV/AIDS prevention (USAIDS, 2003)

In 2000, the South African Government adopted a five-year strategic plan to address HIV/AIDS and sexually transmitted infections that aims to reduce the number of new infections (especially among youths) and reduce the burden of HIV/AIDS on individuals, families and communities (USAID, 2003). With this strategy, emphasis is placed on:

- Promoting safe and healthy sexual behaviour

- Improving the management and control of sexually transmitted infections and opportunistic infections

- Increasing access to and acceptance of voluntary counselling and testing

- Addressing issues related to blood transfusion and HIV

- Reducing prevention of mother-to-child transmission (PMTCT) of HIV

- Providing appropriate post-exposure services

- Improving care and treatment of persons living with HIV/ AIDS (USAID, 2003; HSRC, 2002).

With these targets in place, the National Department of Health designated ' 21 hospitals ( 4 tertiary, 8 regional and 9 district), 12 polyclinics and about 160 clinics for the provision of antenatal counselling, rapid onsite HIV testing and dispensing of Nevirapine' in 2002 (McCoy et al., 2002). It has been estimated that nationally, the proportion of pregnant women with access to HIV counselling and testing as well as Nevirapine treatment is between 12 and 15\% (McCoy et al., 2002). 3133 women per month are tested for HIV in PMTCT pilot sites representing 51\% of pregnant women (McCoy et al., 2002).

\section{Water issues}

\section{The importance of water and sanitation}

Water is essential for life; almost all forms of life are dependent on water. It is the principal constituent of living things and the human body is made up of about $65 \%$ water by weight. The human being can survive for a longer period without food than it can without water (Kleiner, 1999; UN, 2005). Water forms the backbone of the world's economy and it is critical in all spheres of man's activities. It is used for production as in power generation, irrigation and flood plain farming. It is vital to transportation of goods such as crude oil and timber and it is also used for recreation in water sports and holiday resorts which contribute significantly to some economies. Water is also used for a wide range of domestic purposes; laundry, drinking, food preparation and the maintenance of personal and environmental hygiene (Enabor, 1998). Water is vital to development; potable water supply remains a fundamental incentive for socio-economic development of communities.

Water can also serve as an index of the level of development of a community by using parameters such as per capita water consumption. Water consumption increases with the level of development, from 400 to as high as $1500 \mathrm{\ell} / \mathrm{d}$ in metropolitan areas; a child born in the developed word consumes 30 to 50

\begin{tabular}{|l|c|c|c|}
\hline \multicolumn{4}{|c|}{ TABLE 5 } \\
Patterns of $\begin{array}{c}\text { water use by different sectors in } \\
\text { SADC states in 1998 }\end{array}$ \\
\hline $\begin{array}{l}\text { SADC } \\
\text { country }\end{array}$ & \multicolumn{2}{|c|}{$\begin{array}{r}\text { Proportion of water used by } \\
\text { different sectors (\%) }\end{array}$} \\
\cline { 2 - 4 } & $\begin{array}{c}\text { Agriculture } \\
\text { Industry }\end{array}$ & Domestic \\
\hline Angola & 76 & 10 & 14 \\
\hline Botswana & 48 & 20 & 32 \\
\hline DRC & 23 & 16 & 61 \\
\hline Lesotho & 56 & 22 & 22 \\
\hline Malawi & 86 & 3 & 10 \\
\hline Mozambique & 89 & 2 & 9 \\
\hline Namibia & 68 & 3 & 29 \\
\hline South Africa & 62 & 21 & 17 \\
\hline Swaziland & 71 & 8 & 21 \\
\hline Tanzania & 89 & 2 & 9 \\
\hline Zambia & 77 & 7 & 16 \\
\hline Zimbabwe & 79 & 7 & 14 \\
\hline Sairces: Gleich & $1999)$ & \\
\hline
\end{tabular}

Sources: Gleick (1999) and WRI (2000)

times as much water as one born in the developing world (Enabor, 1998; UNICEF/WHO, 2002).

The significance of safe water supply to populations is endorsed as one of the eight principal components of Primary Health Care (WHO, 1978). UNDP (2005) noted that the global Millennium Development Goal of connecting all households to a reliable source of water that is reasonably protected from contamination will be an important step towards improving health and reducing the time spent collecting water. Access to safe water is a fundamental human right which the United Nations Committee on Economic, Social and Cultural Rights adopted on the $26^{\text {th }}$ of November 2006. The South African Constitution states that every citizen has a right to adequate access of water that is not harmful to health (RSA, 1996) and a minimum amount of $25 \ell / \mathrm{cap} \cdot \mathrm{d}$ free of charge is guaranteed. Access to improved water supply is not only a fundamental need and human right, it possesses considerable health and economic benefits and inadequate access to water supply and sanitation limits opportunities to escape poverty and exacerbates the problems of vulnerable groups, especially those affected by HIV/AIDS and other diseases (DWAF, 2003; WHO, 2004).

\section{Profiles of water utilisation in Southern Africa}

Water utilisation profiles in the SADC region are presented in Table 5. The data indicate that in each country, water use for agricultural purposes outweighs those for industrial and domestic use (World Bank, 1998; SADC, 2000). The proportion of water use in the agricultural sector is suggestive of the heavy reliance on food production in each of the countries (Pallet, 1997).

Access of SADC countries to safe water and sanitation services (Table 6) varies considerably and is influenced by the level of urbanisation. Differences in urbanisation among the SADC countries have been widely reported, ranging from $14 \%$ in Malawi to $49 \%$ in South Africa and 64\% in Botswana. Generally, about 69.3 million people constituting $34.4 \%$ of the total SADC population of 201.5 million are residents of formal urban areas while 132.1 million people $(65.6 \%)$ live in rural areas (FAO, 2000; UNAIDS, 2000).

Disparities also exist in the accessibility to safe water supplies and sanitation in urban and rural SADC areas. For example $17 \%, 37 \%, 80 \%$ and $100 \%$ of urban residents in Mozambique, 


\begin{tabular}{|c|c|c|c|c|c|c|}
\hline \multicolumn{7}{|c|}{$\begin{array}{l}\text { TABLE } 6 \\
\text { Comparison of population size, proportion urbanised and levels of access to safe water } \\
\text { and sanitation facilities by urban and rural populations of each mainland SADC country }\end{array}$} \\
\hline \multirow[t]{2}{*}{ SADC country } & \multirow{2}{*}{$\begin{array}{c}\text { Population } \\
\text { in } 2000 \text { (millions) }\end{array}$} & \multirow{2}{*}{$\begin{array}{l}\text { Proportion } \\
\text { urbanised }\end{array}$} & \multicolumn{2}{|c|}{ Access to safe water (\%) } & \multicolumn{2}{|c|}{ Access to sanitation (\%) } \\
\hline & & & Urban & Rural & Urban & Rural \\
\hline Angola & 12.903 & 31 & 69 & 15 & 34 & 8 \\
\hline Botswana & 1.639 & 64 & 100 & 91 & 91 & 41 \\
\hline DRC & 52.046 & 29 & 37 & 23 & 23 & 4 \\
\hline Lesotho & 2.156 & 25 & 65 & 54 & 53 & 36 \\
\hline Malawi & 10.778 & 14 & 80 & 32 & 52 & 24 \\
\hline Mozambique & 19.980 & 35 & 17 & 40 & 53 & 15 \\
\hline Namibia & 1.739 & 37 & 87 & 42 & 77 & 32 \\
\hline South Africa & 43.265 & 49 & 80 & 40 & 79 & 50 \\
\hline Swaziland & 0.928 & 32 & 61 & 44 & 66 & 37 \\
\hline Tanzania & 33.744 & 25 & 67 & 45 & 74 & 62 \\
\hline Zambia & 9.191 & 43 & 64 & 27 & 75 & 32 \\
\hline Zimbabwe & 13.109 & 43 & 90 & 69 & 90 & 42 \\
\hline
\end{tabular}

Sources: CIA (2000); FAO (2000) and UNIADS (2000)

the DRC, South Africa and Botswana respectively have access to safe water. However, in the rural areas of the same countries, in the same respective order, access to safe water supply was reportedly $40 \%, 23 \%, 40 \%$ and $91 \%$ (FAO, 2000; UNAIDS, 2000). Generally, 43.1 million people (62\%) of all urban residents have access to safe water. Access to sanitation in urban and rural areas of Mozambique (53\% vs. $15 \%$ ), DRC ( $23 \%$ vs. $4 \%$ ), South Africa (79\% vs. $50 \%$ ) and Botswana (91\% vs. $41 \%$ ) also reveal stunning disparities in favour of urban areas. In a nutshell, only $45 \%$ of the total SADC population have access to safe water supplies while only $40.5 \%$ have access to sanitation facilities (FAO, 2000; UNIAIDS, 2000; Ashton et al., 2002).

In South Africa, water infrastructure is well developed in urban areas and the majority of the urban population utilise potable water. In rural communities, water infrastructure is either poorly developed or non-existent and the majority of the population rely on water sources such as rivers and ponds for their drinking water (Obi et al., $2003 \mathrm{a}$; b). These water sources are usually not pretreated, are faecally contaminated and unsafe for human consumption (Obi et al., 2002; 2003 a;b; Momba et al., 2000; Muyima and Ngcakani, 1998). Contaminated water sources are vehicles for the transmission of water-borne diseases such as cholera, shigellosis and Campylobacteriosis (Ashbolt, 2004). Several bacterial enteropathogens namely Campylobacter jejuni/coli, Salmonella spp., Shigella, Plesiomonas, Aeromonas, Vibrio cholerae, Giardia lamblia and Escherichia coli were also isolated from the river water sources (Obi et al., 2002). These enteric bacterial pathogens are variously incriminated in cases of diarrhoea, which accounts for a substantial degree of morbidity and mortality in different age groups world-wide (Black, 1993; Pracho and O'Ryan; 1994; Obi et al., 1997; 1998; 2003 a; b; 2004; El-Sheikh and El-Assouli, 2001).

Since around the $19^{\text {th }}$ century, outbreaks of diseases like cholera have emphasised the necessity of disinfecting drinking water. The World Health Organisation (WHO) estimates that about 1.1 billion people globally drink unsafe water and the vast majority of diarrhoeal diseases in the world (88\%) are attributable to unsafe water, sanitation and hygiene. Approximately $3.1 \%$ of annual deaths ( 1.7 million) and $3.7 \%$ of the annual health burden (disability adjusted life years [DALYs]) world-wide (54.2 million) are attributable to unsafe water, sanitation and hygiene (WHO, 2003).

Drinking water can also be contaminated by sewage (Ljung- strom and Castor, 1992). Sewage treatment plants are employed in the treatment of wastewater. Wastewater is defined as water that carries wastes from homes, businesses, and industries, for which disposal is more economical than use at the time and point of its occurrence. Wastewater components show different degrees of environmental nuisance and contamination hazards due to their chemical and microbiological characteristics (Bohdziewicz and Sroca, 2004). Outbreaks of cholera, salmonellosis, cryptosporidiosis and giardiasis have been linked to the contamination of drinking water by sewage (Ljungstrom and Castor, 1992). It is therefore clear that the management and treatment of wastewater for the reduction of the amount and number of pathogens is important to maintain a healthy and clean environment. Wastewaters from home, commercial buildings and hospitals are collected via a collection system and flow to sewage treatment plants (STPs) for treatment. In addition to domestic sewage, effluents from industrial facilities are sometimes also discharged into municipal STPs for further treatment before being released into the environment. Different methods are used for the treatment of sludge in an STP. These include: Sedimentation, mesophilic or thermophilic anaerobic digestion, composting, storage or by a combination of these methods (Sahlstrom et al., 1994). These treatments participate in the inactivation of pathogenic micro-organisms. The treatment processes might also impact on physicochemical parameters of the final effluent such as biochemical oxygen demand (BOD), chemical oxygen demand (COD), electrical conductivity, total hardness, alkalinity, dissolved oxygen and some metals and non-metal ions (Rawat et al., 1998). At the end of the treatment process sludge and final effluent are released to nature.

Effluents from the STP can be reused for agricultural and industrial purposes, for land application, or recycled and used as drinking water (Weinberg et al., 2004). These effluents when discharged into the river constitute an important health risk for the population using this water for other purposes such as for doing laundry, bathing or even drinking, if not disinfected. Sludge from STPs is generally used as fertilisers by the population or by agricultural companies. Different groups of microorganisms have been described in sludge including viruses (pike 1986); bacteria such as Salmonella spp., Campylobacter, Listeria monocytogenes and Escherichia coli (Sahlstrom et al., 1994); parasites such as cryptosporidium, Giardia lamblia and Entamoeba histolytica (Robertson et al., 2000). Studies in other 
countries such as Sweden, China, Poland and Australia have described different methods and efficiency of STPs in reducing pathogens in wastewater (Horan et al., 2002; Chen et al., 2004).

However, very little literature exists on the efficiency of sewage treatment in developing countries such as South Africa. Regular monitoring of microbiological content of sewage and final effluent from STPs will illuminate knowledge of the microbial population in the human community and contribute to the understanding of epidemiological patterns of diarrhoeal diseases. This monitoring will also help in improving the methods of sewage treatment and this will be important in protecting the environment and human and animal life against pathogenic organisms.

In order to prevent water-borne diseases, water is treated to eliminate pathogens. In rural and peri-urban areas, water sources are usually treated in units called small water treatment plants (SWTPs). SWTPs are defined as water treatment systems that are installed in areas, which are not well serviced, and which do not normally fall within the confines of urban areas. They are therefore mostly plants in rural and peri-urban areas and include water supplies from boreholes and springs that are chlorinated, small treatment systems for rural communities, treatment plants of small municipalities and treatment plants for establishments such as rural hospitals, schools, clinics, forestry stations, etc.

Most of these applications fall within the category of small plants of less than $2.5 \mathrm{M} \ell / \mathrm{d}$, although plants of up to $25 \mathrm{M} \ell / \mathrm{d}$ may sometimes also fall into this category. Management and administration of SWTPs might determine the quality of final water. Generally, people working at SWTPs are called operators. Their main role in the plant is to control the equipment and processes that remove or destroy harmful materials, chemical compounds, and micro-organisms from the water. Their knowledge is thus important in the provision of water of good quality. During the past century, drinking water treatment has been improved with the standardisation of process treatment. This process generally includes: pre-disinfection of water coming directly from the river, coagulation-flocculation, sedimentation, filtration and post-disinfection. Coagulation removes dirt and other particles suspended in water. Alum and other chemicals are generally added to water to form tiny sticky particles called 'floc' which attract the dirt particles. The combined weight of the dirt and the alum (floc) become heavy enough to sink to the bottom during sedimentation. During filtration, the water passes through filters, some made of layers of sand, gravel, and charcoal that assist in removing even smaller particles. A small amount of chlorine is added or some other disinfection method is used to kill any bacteria or micro-organisms that may be in the water. Filtration and disinfection are the critical points of the treatment process. Different filtration systems can be used and the most common material used is sand in slow sand filtration, rapid gravity sand filtration or in some cases pressure filters. Disinfection is commonly done by chlorine (in different forms), ozone and ionisation (Zhanga et al., 2004), but disinfection may not be effective due to several administrative and technical issues, leading to the presence of pathogens in drinking water sources.

Isolation of pathogens from water sources connotes a serious public health risk for consumers. To further compound this problem, enteric bacterial pathogens have been widely reported to demonstrate resistance to several antibiotics (Hoge et al., 1998; Obi et al., 1998; McArthur and Tuckfield, 2000; Engberg et al., 2001; Ash et al., 2002). For example, in 1984, 82\% of Campylobacter strains from Lagos, Nigeria, were sensitive to erythromycin, and 10 years later only $20.8 \%$ were sensitive (Coker and Adefeso, 1994). In Thailand, ciprofloxacin resist- ance among Campylobacter species increased from $0 \%$ before 1991 to 84\% in 1995 (Hoge et al., 1998). Strains of S. typhi with multiple resistance to chloramphenicol, ampicillin and trimethoprim have led to several outbreaks (Rowe et al., 1997). In the United States, several rivers were reported to be reservoirs of antibiotic-resistant bacteria (Ash et al., 2002). Antibiotic resistance may occur spontaneously, by selective pressure or because of antibiotic abuse by humans or over-use in animals (White et al., 2000). Although antibiotic resistance is common, antibiotics are still indicated in the management of diarrhoea. Antibiotics shorten the duration of diarrhoea, decrease stool output and may mitigate complications (Black, 1993).

In spite of the poor water quality in rural communities of Limpopo Province, studies on antibiotic susceptibilities of bacterial isolates from water sources have received only cursory attention. Such data, if available, will be useful in the empiric management of patients with diarrhoea because antibiograms vary with time and geographical region.

\section{Water, sanitation, hygiene and health}

Poor water quality and lack of access to improved sanitation continue to pose a major threat to human health. Burden of disease analysis suggests that lack of access to safe water supply, sanitation and hygiene is the $3^{\text {rd }}$ most significant risk factor for poor health in developing countries with high mortality rates (Tumwine et al., 2002; WHO, 2002). Diarrhoea is one of the diseases associated with unsafe water supply, sanitation and hygiene and is a major cause of childhood morbidity in subSaharan Africa (Boadi and Kuitunen, 2005). According to the WHO/UNICEF Joint Monitoring Program carried out in 2002, diarrhoeal diseases caused approximately 6000 deaths/d mostly among children, and between 1085000 and 2187000 deaths due to diarrhoeal diseases could be attributed to the water sanitation and hygiene risk factor (UNICEF/WHO, 2002).

Water is related to disease in various ways. It serves as a route of transmission, e.g. cholera; a breeding site of a stage of the lifecycle of the infective agent, e.g. malaria; a harbour for the carrier of the infective agent, e.g. schistosomiasis.

In recognition of the critical role of water and sanitation in the quality of life of human populations, there is concerted effort, globally and locally to put in place various programmes to eradicate the backlog of people without access to safe water and sanitation. The Millennium Development Goal's $10^{\text {th }}$ target is the halving by 2015 of the proportion of people without sustainable access to safe drinking water and sanitation. The South African Government has also launched an accelerated water and sanitation delivery programme with the aim of addressing the water and sanitation backlog by 2008 and 2010 respectively.

\section{Water supply, sanitation and hygiene provision}

In spite of the collaborative efforts to eradicate the backlog of people without access to water and sanitation, a marked inaccessibility still exists in most developing countries.

The UNICEF/WHO (2005) noted in their Joint Monitoring Program for Water Supply and Sanitation (JMPWSS) that in the year 2000, 1.1 billion people globally were without access to an improved water supply (amounting to 2 out of 10 persons) with 700 million of these residents in Asia and nearly 290 million in Africa. The JMPWSS noted further that 2.4 billion people were without access to improved sanitation, i.e. 4 out of 10 persons. In a budget speech on 10 May 2002, the South African Minister of Water Affairs and Forestry noted that the cholera 
outbreak in KwaZulu-Natal and other parts of the country was a wake-up call in terms of accelerating the provision of water, sanitation and hygiene awareness, and it has brought attention to the unavoidable fact that not enough has been done in terms of delivering sanitation and promoting simple but critical health and hygiene. (DWAF, 2003).

In order to achieve the global and local targets, the $U N$ World Water Development Report (UNICEF/WHO, 2004) noted that an additional 1.5 billion people will require access to some form of improved water supply by 2015, that is an additional 100 million people each year until 2015 (274 000/d).

In view of the limited resources and the vast numbers of people without adequate water and sanitation supply, there is a need in the sector to determine resource allocation priorities for addressing the backlog. There is agreement in the sector that the health and economic benefits of improved water and sanitation supply are compelling enough to support resource allocation towards eradicating the backlog of people without access to water and sanitation.

However, priorities need to be agreed upon and interventions have to be those which have the highest cost benefit. Some of the possible benefits include averted health costs, avoided lost days, and time from daily activities due to less illness, time-saving associated with having water and sanitation facilities closer to home. Time-saving may translate into higher productivity, higher school attendance and more leisure time. Decisions on prioritisation of interventions will be based on issues such as the need to focus on areas of greatest lack and the potential health impact of separate or integrated interventions.

\section{Differences in urban and rural water and sanitation access}

There is a difference in water and sanitation coverage between urban and rural areas at the global, regional and country levels, which creates a relationship between access and socioeconomic status.

The UNICEF/WHO Joint Monitoring Program for Water and Sanitation (2004) reported that in the decade between 1990 and 2000,537 million vs. 365 million people (i.e. 172 million more people) were provided with water in the urban and rural areas globally. Regionally, the percentage of the people not served with improved water supply is $36 \%$ of the total African population. Within countries UNICEF/WHO (2004) estimated that the water supply coverage in rural areas was on average only $50 \%$ compared with $86 \%$ coverage in urban areas, with the water supply coverage in Kenya being about $80 \%$ of the total urban population compared to $20 \%$ of the rural population. The WHO (2004) noted that in sub-Saharan Africa, sanitation coverage was a mere $36 \%$ with only $31 \%$ of the rural inhabitants in developing countries having access to improved sanitation as opposed to $73 \%$ of urban dwellers.

\section{Potential health impact of improved sanitation}

There is agreement that improved sanitation has an impact on health and reduces diarrhoea morbidity by $32 \%$ (WHO, 2004). Sanitation facilities interrupt the transmission of faecal/oral disease at its most critical point, i.e. the prevention of human faecal contamination of water. Studies suggest that sanitation is at least as effective in preventing disease as improved water supply. Hossain et al. (2003) in a study carried out between 1999 and 2000 to investigate the impact of sanitation and health education on intestinal parasite infection among school-age children of
Sherpur, Bangladesh found that intestinal parasite infection was significantly lower $(\mathrm{P}=0.05)$ among those who used a sanitary latrine and received health education. The association between stool disposal and diarrhoea has been investigated in a number of epidemiological studies. Indiscriminate defecation around living areas was found to be associated with an increased incidence of diarrhoea (Stanton and Clemens, 1987; Han and Moe, 1990). Baltazar and Solon (1989) found a $64 \%$ increase in pathogen-positive diarrhoea in families where children's stools were inadequately disposed of. Mertens et al. (1992) reported that unsafe stool disposal was associated with a 54\% greater diarrhoea risk in Sri Lanka and deduced that if such practices were reduced from $91 \%$ to $50 \%$ of the population, then $12 \%$ of diarrhoeal episodes could be prevented. A further source of evidence for the importance of safe stool disposal is the literature on the impact of sanitation programmes in developing countries. If the construction of latrines reduces diarrhoeal disease, then the effect is presumably due to the safe disposal of stools. Rahaman et al. (1985) found that post-neonatal mortality rates were $68 \%$ lower in families with latrines than in those without. Daniels et al. (1990) suggested that the presence of a latrine may reduce diarrhoeal infection by a quarter, especially in households with good hygiene practices.

\section{Integrated water, sanitation and hygiene provision}

Water, sanitation and health are inseparably linked.The improvement of hygiene practices through key behaviour such as handwashing with soap, safer water handling and storage and safe disposal of children's faeces are effective means of reducing global burden of diarrhoeal diseases (Curtis et al., 2000; Curtis, 2003; WHO, 2004). In a study of the impact of hygiene on diarrhoea incidence in children, the prevalence of diarrhoea among children for whom unhygienic behaviour was recorded was 2.2 times higher than in children in the hygienic group (Brooks et al., 2003; Strina, 2003).

In spite of the significant scope for improving hygiene practices at home to prevent infection and cross-infection, personal and domestic hygiene practices cannot be improved without basic amenities such as water supply, wastewater disposal and solid waste management (Nath, 2003). An evaluation of the benefits of integrated water, sanitation and hygiene programme (WASEP) showed that children not living in WASEP villages had a $33 \%$ higher adjusted odds ratio for having diarrhoea than children living in WASEP villages and interventions in hygiene, sanitation and water supply have been shown to control the disease burden (Nanan, 2003; Thompson et al., 2003).

\section{Bacterial pathogens in water}

The processes used for producing potable water are not intended to produce bacteria-free water; rather, they are concerned with removing micro-organisms that are a potential health threat and making water aesthetically pleasing. The types of processes used to treat water appear to have relatively little effect on the types of bacteria that can pass through the treatment process, although disinfection with oxidising disinfectants will tend to remove vegetative bacteria, whereas bacterial spores may well be unaffected. It is well-understood that there are many factors that affect an organism's susceptibility to chlorine disinfection, and one of the major factors appears to be the degree of metabolic activity.

As our knowledge of clinical microbiology increases and epidemiological surveillance improves, the range of micro- 
organisms that have been shown to cause water-borne diseases has grown. These include viruses such as rota viruses, Norwalk viruses, calici-like viruses; protozoa such as Cryptosporidium, Entamoeba histolytica and bacteria such as Campylobacter, Salmonella, Shigella, Escherichia coli, Vibrio cholerae and Aeromonas.

\section{Aeromonas spp.}

The significance of these environmentally ubiquitous organisms in the aetiology of human gastrointestinal diseases is documented (WHO, 2002). While certain species, mainly $A$. caviae, $A$. hydrophila and $A$. veronii subspecies sobria, have been isolated from patients with diarrhoea (Ashiru et al., 1993; Obi et al., 2004), these organisms are also found frequently in the faeces of subjects who are asymptomatic. There is no doubt that Aeromonas can frequently be detected in a variety of waters, and several investigators have described its detection in potable water (Havelaar et al., 1990) at levels of up to 1 $900 \mathrm{cfu} / \mathrm{m} \ell$. However, even with modern tools for discrimination between bacterial isolates, it is difficult to determine if the types of organisms present in drinking-water are the same as those found in patients with diarrhoea. Havelaar and colleagues (Havelaar et al., 1992) used serotyping and cell-wall fatty acid analysis to attempt to correlate the presence of Aeromonas in drinking water and in patients with diarrhoea. The differences they encountered between the strains from the two sources led them to conclude that the strains isolated from water were essentially different from those isolated from human faeces. Similar studies (Hanninen, 1994; Kirov et al., 1994) failed to confirm a link between the strains found in drinking-water and those isolated from human faeces.

Aeromonas is also frequently found in foods, and many studies have been carried out to determine its incidence. In all published studies, Aeromonas was found in a variety of foodstuffs with isolation rates of up to $84 \%$ and concentrations of up to $10^{5} / \mathrm{g}$, with ready-to-eat foods being frequently contaminated (Hanninen, 1993). In human volunteer experiments, doses of $10^{10}$ failed to produce diarrhoea, and many subjects did not excrete the organism. However, the pathogenic traits of the inoculums were not clearly defined. However, Albert et al. (2000) examined the distribution of virulence genes such as the cytotoxic enterotoxin gene act (encoding Act) and the cytotonic enterotoxin genes alt (encoding Alt) and ast (encoding Ast) in aeromonad isolates from children with diarrhoea, healthy matched controls, and the environment. Their objective was to determine the association between these enterotoxin genes and to identify a new virulence property or properties that may, possibly in combination with other virulence traits, contribute to diarrhoea using polymerase chain reaction (PCR). The results showed that there was circulation of strains between humans and the environment.

\section{Salmonella}

An increase in the frequency and severity of non-typhoid strains of Salmonella has been reported in patients with AIDS and may be an initial manifestation of AIDS (Sperber and Schleupner, 1987). Salmonella typhimurium and Salmonella enteritidis were reported to be the most commonly isolated species from HIV/ AIDS patients (Levine et al., 1991).

In the developing world, HIV infection and AIDS are important risk factors for non-typhoid salmonellosis and bacteraemia. Non-typhoid Salmonellae are among the most common pathogens isolated from patients with diarhoea.

\section{Campylobacter}

Campylobacter jejuni is the most common species isolated from HIV/AIDS infected people. The genus Campylobacter consists of several species including, Campylobacter jejuni, C. coli, C. lari and C. upsaliensis which are the most important species, with $C$. jejuni and $C$. coli accounting for the majority of human infections. Raw milk, untreated surface water, and poultry meat have been shown to be major sources of $C$. jejuni and C. coli infections (Corry and Atabay, 2001). A number of PCR protocols, targeting different genes within the genus Campylobacter, or specifically within the species $C$. jejuni and $C$. coli, have been developed and applied for detecting and identifying these organisms(Corry and Atabay, 2001).

\section{Vibrio}

Vibrio spp. are known to cause diarrhoea. However, the most important causes of diarrhoea in humans are Vibrio cholerae and Vibrio parahaemolyticus. Dependable discriminatory molecular methods have been developed for epidemiological examination of $V$. parahaemolyticus. Molecular typing of clinical and environmental isolates analysed by molecular methods showed that polymorphic patterns recognised were of the major types and were closely related to each other (Wong et al., 1999).

\section{Escherichia coli}

Obi et al. (2004) employed PCR to evaluate the genetic relatedness of isolates from patients with diarrhoea and from water sources. The results indicated that $E$. coli genes found in patients' diarrhoeal stools were similar to those isolated from water sources. It was concluded that water could be the possible source of infection.

The PCR is a rapid and reliable tool for the molecular diagnosis of pathogens. It has been utilised to identify enteric pathogens in water and stool specimens (Obi et al., 2004). Pulse field gel electrophoresis (PFGE) was used to genetically type isolates from stool samples of patients as well as isolates from environmental samples. The vast majority of the enteric pathogens such as E. coli O157:H7, Vibrio, Salmonella and Aeromonas isolates from stool samples of patients and water sources were of one related type, suggesting primary contamination of water (Hilborn et al., 2000). This actually implicates water distribution systems as the main sources of exposure in outbreaks such as the typhoid fever outbreak in Delmas, Mpumalanga.

\section{Linkages between HIVIAIDS and water, sanita- tion and hygiene}

The HIV/AIDS epidemic has caused substantial morbidity and mortality in different age groups world-wide. Water-borne diseases, in turn, are responsible for a vast array of debilitation and death in different age groups world-wide, particularly in rural communities.

At a superficial observation, issues around HIV/AIDS and water may appear not to be connected because HIV is transmitted sexually, whereas water is a renewable natural resource, a sine qua non for life. On closer analysis, the intricate web of relationships existing between water and HIV/AIDS cannot be underestimated. Indeed some of the easily discernable consequences of HIV/AIDS are the long-term implications for effective water resource management and the provision of potable/ clean water to communities (Ashton, 2002) 
Consequently, an exploration of the linkages and perspectives between HIV and AIDS and water will enhance development of integrated approaches. Several aspects of the linkages between HIV/AIDS and water exist and are as follows:

\section{The health aspects}

The water supply sector is tasked with the responsibility of improving the health of the population by providing access to safe water. Water services are limited in communities with high prevalence of HIV/AIDS. These services, when adequate, may prevent faecal/oral transmission of diarrhoea-causing agents. People with compromised immune systems are prone to these diseases and without potable water supply may suffer from persistent diarrhoea. Immune systems of HIV-positive individuals are prone to a wider range of common illnesses and diseases than individuals whose immune systems are not compromised by HIV/AIDS. HIV individuals therefore have greater requirements for potable water than un-infected individuals (Ashton, 2000). The most affected are the poor, who represent the fastest growing sector of HIV/AIDS afflicted and are very likely to suffer from diarrhoeal diseases, caused by unsafe water. While it is true that unsafe water is a public health risk, there is evidence that providing safe water has a positive impact on individuals living with HIV/AIDS. Improving water quality will also lead to a decline in childhood and adult deaths as well as diarrhoeal diseases in people living with HIV/AIDS (UNAIDS, 2003; UNICEF, 2003)

One of the hallmarks of HIV/AIDS is diarrhoea (Prasad et al., 2000) and about $90 \%$ of HIV/AIDS patients in Africa suffer from chronic diarrhoea (Janoff and Smith, 1998). The substantial degree of morbidity and mortality due to diarrhoeal diseases in developing countries is thus compounded by the HIV/AIDS epidemic (Obi and Bessong, 2002). Diarrhoeagenic enteropathogens include bacteria such as Campylobacter, Salmonella, Shigella, Vibrio, Escherichia coli, Aeromonas and Plesiomonas (Obi et al., 2003). These pathogens are waterborne and their association with HIV/AIDS typifies a link, which implicates water quality in some clinical manifestations of HIV/AIDS. Campylobacter-associated diarrhoea and bacteraemia occur world-wide in HIV/AIDS patients (Quin, 1997; Lastovica et al., 2001). The incidence of clinical manifestations of campylobacteriosis is higher in HIV-positive than in HIV-negative patients, with substantial mortality and morbidity.

In addition, high infection burdens of diarrhoeagenic bacteria have been reported in developing countries especially in communities with high HIV and AIDS prevalence, poor sanitation and inadequate water treatment (Clark, 1999).

\section{Infant feeding}

Water quality and breast-feeding is a dilemma of mothers living with HIV/AIDS. HIV positive mothers without access to safe water are at a crossroads as to whether to pass on the infection to their babies or deny them breast milk (UNICEF, 2004). Unsafe water used in infants feed increases the risk of diarrhoeal diseases and infant mortality (Dunne et al., 2001).

\section{Anti-retroviral treatment}

Safe water is also needed during HIV medications. Anti-retrovirals (ARVs) or treatment for opportunistic infections in HIV/ AIDS requires the use of safe water. Several links therefore exist between HIV/AIDS and water quality: In fact providing safe water to people living with HIV/AIDS reduces AIDS related mortality (Lule et al., 2005).

However, it should be noted that the mere provision of safe water and sanitation may not guarantee improvement of health except if it is complemented with hygiene promotion and appropriate hygiene behaviour (IRC, 2004). Improved water handling and sanitation practices, personal hygiene and safe water disposal and drainage are necessary adjuncts for the reduction of water-borne diseases and these factors are even more important for people living with HIV and AIDS and family members of HIV positive people. Hygiene education should therefore focus on care-givers and volunteers involved in home-based care but this is not as yet commonly practiced.

\section{Access to water and latrines}

In addition to providing safe water, supply points and latrines have to be close to points of use. This will reduce the long distances that residents undertake to fetch water, particularly caregivers, weak or ill individuals, and also reduces vulnerability to infection with HIV because it obviates the risk of girls and women being raped while fetching water.

Moreover, the design of water systems should be unique pumping not too laborious for the immuno-compromised (HIV and AIDS patients), children and the elderly who may be saddled with the task of fetching water. Consequently, improved access to water supply may result in labour-saving benefits to HIV/AIDS affected households.

\section{Burial sites}

The stigmatisation of HIV and AIDS has resulted in HIV infection to be shrouded in secrecy and this has precipitated 'the legacy of shame' attached to HIV infected and affected households. This has also caused some family members of HIV and AIDS victims not to announce the death of relatives, with consequent burials in unofficial graveyards. Such graveyards may be sources of contamination of groundwater supply. While this dictum is not suggestive of potential transmission of HIV to groundwater, it may be associated with elevated nutrient levels and bacterial contamination from graves permeating groundwater systems (Engelbrecht, 1998).

\section{Poverty alleviation aspects}

HIV and AIDS are impediments to achieving global poverty reduction targets and development goals. Poverty enhances vulnerability to HIV infection and AIDS exacerbates poverty. Although HIV and AIDS affect the rich and the poor, the impact is higher among poor households, where female vulnerability is heightened because prostitution may be one of several coping strategies.

Poor access to basic amenities such as health care, water and sanitation which are also indices of poverty may increase vulnerability to HIV infection. In South Africa, the tension between the allocation of financial resources to combat HIV and AIDS and to solve low coverage of safe water supply and sanitation in rural poor communities must be cautiously mediated because water is a basic and strategic imperative for poor people and for HIV and AIDS infected people (IRC, 2004). Adequate water supply has been reported to save labour and energy, reduce health expenditure, generate nutritional value and has other ripple effects on sustainable livelihood. 


\section{Gender aspect}

Gender imbalance is the critical hinge in the overlap between socio-cultural and economic impacts of HIV and AIDS. Oppressive customs and traditions may create reduced economic power for women and fan the spread of HIV. Women are affected disproportionately because of their socially defined roles such as caring for family members, partners, child-bearing and -rearing and other domestic responsibilities such as fetching water and transportation across long distances. Water supply can therefore be of value to women in terms of meeting their practical needs (IRC, 2004). Safe water provision many also enhance sustainability of livelihoods

\section{Community-driven development aspect}

IRC (2004) reported that in the water and sanitation sector, a relationship might exist between the level of community organisation, empowerment and autonomy and the level of sustainability of water and sanitation interventions. Factors that are of importance in this connection are community cohesion, stable traditional leadership and respect for ethnic division. These factors also typify the ability of communities to cope with the impact of HIV and AIDS and to prevent new infection.

In a nutshell, community management in the water sector equates to community HIV and AIDS competence. A community-based organisation may create social cohesiveness and a good platform for awareness and education campaigns, behavioural change communication and thus reduce vulnerability to HIV and water-borne diseases.

\section{The human rights aspects}

Stigmatisation of HIV and AIDS has made the disease a human rights issue because certain indicators around HIV and AIDS containment, lack of accessibility to prevention methods, treatment, care and support are associated with human rights violations. These indicators include poverty, inequality, racialism and sexism. HIV and AIDS infected individuals may be constrained to live a fully dignified and free life due to violations of their rights on the basis of their HIV status. International organisations such as UNAIDS, UNICEF, UNDP, UNESCO, WHO, ILO and the World Bank are entrenching human rights principles in HIV and AIDS prevention, treatment, care and support.

The water and sanitation sector also has a human rights perspective. Access to safe water and sanitation is not just regarded as a mere basic need but also a human right. The water supply and sanitation collaborative council in its Vision 21 canvassed an encompassing approach regarding water, hygiene and sanitation as a human right juxtaposed in the context of human development, poverty reduction, environmental sustainability and integrated management of water resources (IRC, 2004).

Furthermore, 'The Civil Society Action Programme on Water' during the World Summit for Sustainable Development asserted that secure access to sufficient safe water and sanitation to meet basic human needs, including water for small-scale production to support livelihoods is indeed a human right. The focus on provision of water as a human right is tangential to policy and programmatic strategies, particularly for countries with high prevalence of HIV and AIDS because it impinges on sustainable effort and increased financial outlay to realise total coverage.

\section{Productive aspect of water}

It has been reported that food security is increased by access to water and this, in turn, enables people to stay healthy. Nutrition is also improved by making food softer and easier to eat by mixing it with safe water. This is particularly good for people who have mouth ulcers or oral thrush as a result of HIV/AIDS and cannot eat solid foods. Water may also be useful for income generation such as in brewing, food production and tending of livestock (Kamminga and Wegelin-Schuringa, 2003).

Consequent upon the examination of the various aspects of the links between HIV/AIDS and water, it would be pertinent to explore the impact of the disease on the water sector.

\section{Impact of HIV and AIDS on demand for water and sanitation services}

The demand for water and sanitation may be affected by the pandemic because the scepticism around predictions of mortality due to HIV and AIDS and population growth rates may impact on the planning and implementation of water supply and sanitation systems (Ashton, 2000). Population growth rates and life expectancy are on the decline because HIV reduces fertility and more children die due to HIV and AIDS. In fact it has been reported that the chances that boys of 15 years of age will die of AIDS in Kenya, Zambia, South Africa and Botswana are $50 \%, 60 \%, 70 \%$ and $90 \%$, respectively (UNAIDS, 2000). This gloomy situation will certainly lead to a decrease in the demand for water supply and sanitation services (Pallet, 1997; Whiteside and Sunter, 2000; Ashton, 2000). Indeed failure to place water demand estimates within the context of HIV- and AIDS-related mortality, would lead to an overestimation of water demand by between 10 and $30 \%$ (Ashton, 2000). This scenario would result in unanticipated consequences for the water supply sector. It could also be argued that the demand for water may increase as a consequence of an urban-rural migration, because most of the infected individuals opt to return to rural home areas during the terminal stages of the disease (UNAIDS, 2002; White and Robinson, 2000). At the moment there is a migration of people to urban areas in search of employment.

\section{Faltering payment of water services}

HIV and AIDS are financially disempowering as a result of loss of income due to ill health, increased medical cost and general livelihood insecurity. This places expenditure on water in competition with medical bills, school fees and other survival instincts; with a consequent return of affected households to unprotected and unsafe water sources (Ashton, 2001). HIV and AIDS cause family collapse due to the fact that the middle generation are either severely ill or deceased, leading to a shift of parenting to the very young or the elderly (Laurie, 2000; Karim, 2000). In such cases child-headed households and elderly relatives become common. This creates enormous social problems because the very young and elderly are unable to engage in intensive productive ventures and thus rely on government support for their livelihoods (UNAIDS, 2000; Whiteside and Sunter, 2000). The consequences are unmet needs for basic services such as water supply and sanitation, electricity, housing and education. Child-headed households may also be unaware of safe water handling procedures.

Households with economically active adults may experience a shift in expenditure on water and sanitation services to health care for sick family members. The ultimate consequence is that 
the state will be overburdened and that water supply agencies would have to cope with the huge responsibilities of providing water supply and services.

\section{Erosion of social capital and waning productivity}

In this context, erosion of social capital embodies the loss of knowledge and skills. Social capital is fuelled by people in the productive years (20 to 50 years) of age. Coincidentally, this is also the age group most affected by HIV and AIDS (UNAIDS, 2000; Williams et al., 2000). As a result of the anticipated reduction in the profile of skilled and semi-skilled workers due HIV and AIDS, the ripple effects will include the need to recruit replacements, high rates of employee turnover, heavy demands on the available workforce, increased demand for training, decreased productivity, costly delays and unsafe work practices (Morris and Cheevers, 2000; Ashton, 2000; Williams et al., 2000).

The aforementioned effects, while not exclusively confined to the water sector, would affect operators of water treatment works and sewage treatment works. The operators have been pin-pointed because they play a crucial role in the management of water resources and provision of water supply for domestic and industrial use (Ashton et al., 2000). Increased turnover of water and sewage treatment operators, to whatever degree, will attract a corresponding increase in the recruitment and training of replacement operators (Ashton, 2000). Prevarication in training will affect the performance of treatment plants and the untoward decline in potable water quality and predisposition to water-borne diseases (Ashton, 2000).

HIV and AIDS have also been reported to lead to a decline in productivity as a result of frequent absenteeism due to a progressive level of ill health and ultimate decline in worker productivity (UNAIDS, 2000; Crewe, 2000; World Bank, 1999). Frequent attendance of funerals by employees causes depletion in annual working days and decline in productivity (Heywood, 1999). Additional burdens to employers may include cost of treatment for opportunistic infections, funeral cost and payment of benefits.

\section{Mainstreaming of HIVIAIDS in the water sector}

Consequent upon the relationship between water and HIV/ AIDS, the water sector should therefore strategise on policy and programmatic issues in terms of empowerment of local women, people living with HIV/AIDS and their care-givers and propoor financing mechanisms including focus on water for health and economic benefits. Others should include development of workplace policies, adaptation and reorganisation of workload, development of strategies for reserve staff, adjustment of performance appraisal systems to manage impact on productivity and integration of HIV/AIDS into all training activities (Kamminga and Wegelin-Schuringa, 2003). Furthermore, how HIV/ AIDS will affect water and sanitation programmes such as target groups, objectives, human and financial resources or vice versa should be emphasised.

\section{Responses to HIV and AIDS in the water sector}

There is a paucity of data to convincingly authenticate a concerted response to the multitude of implications of HIV and AIDS in the water resource management sector in Southern Africa (Ashton et al., 2002). Some government departments dealing with water-related issues have called for national and regional appraisals of the implications of the pandemic for their activities whereas others have reiterated the need for additional training programmes in the wake of increased staff turn-over, decreased worker productivity and associated HIV- and AIDSrelated cost increases.

Educational campaigns to enhance public awareness of the pandemic and implications for individuals, communities and the society, as well as counselling services for infected and affected people have been in the forefront as a result of concerted efforts by national departments in most Southern African countries. In South Africa, some activities of the state are associated with the linkages between HIV and AIDS and the water sector. These activities include efforts to provide safe water and sanitation services for poor rural and urban communities. Although these activities were initially undertaken to address historical antecedents that created lopsidedness in the distribution of basic amenities in the previously disadvantaged communities, they also reduce the risk of exposure of HIV and AIDS patients to poor water quality (Ashton et al., 2002).

Although responses to HIV and AIDS in South African Government departments or parastatal entities appear to be fragmented and somewhat devoid of the benefits of the advantages of integration, each departmental approach holds great promise (Ashton et al., 2002) and this further underpins the need for consolidation and integration efforts. However, it should be noted that there is no single ideal response or universal blueprint, as a preferred or overriding choice to combat the scourge of the century.

Political commitment at the topmost level is imperative for stemming the impact of the pandemic. Commitment encourages disclosure, reduces stigma and enhances multi-sectoral approach in collaboration and partnership with civil society and the private sector (Kamminga and Wegelin-Schuringa, 2003). The advantages of commitment at the highest level are exemplified by the reduction of HIV/AIDS prevalence in Uganda, Thailand and Senegal. Government's commitment may be complemented by involving people affected by HIV/AIDS in the planning and execution of developmental issues.

Managers in the water resource sector should have reliable data or forecast for the demographic spread of water demand to ensure that poor communities, devoid of the ability to pay for water services are not neglected in terms of water supply.

In order to reduce the health impact of ineffective water treatment as a result of HIV and AIDS related mortality of water treatment operators, innovative water treatment processes that do not require regular or constant supervision or management activities should be explored, developed and eventually implemented (Ashton et al., 2002). Another responsibility of the water sector is to give impetus to awareness programmes aimed at unravelling the implications of untreated water and inadequate personal and environmental hygiene practices.

Although a relationship exists between poor water quality, diarrhoea and HIV/AIDS, there is a dearth of knowledge or paucity of information on the intricate link between water quality, diarrhoea and HIV/AIDS in some communities in South Africa. This article attempts to narrow such gaps of knowledge of HIV/ AIDS and water quality.

\section{References}

ABDOOL KARIM SS (2000) Rising to the challenge of the AIDS epidemic. S. Afr. J. Sci. 96 (6) 262.

ALBERT M J, ANSARUZZAMAN M, TALUKDER K A, CHOPRA AK, KUHN I, RAHMAN M, FARUQUE ASG, ISLAM M S, SACK RB and MOLLBY R (2000) Prevalence of enterotoxin genes in Aeromonas spp. isolated from children with diarrhea, healthy 
controls, and the environment. J. Clin. Microbiol. 38 (10) 3785 3790 .

ANON (1994) The Microbiology of Water. Part 1 - Drinking Water. Report on Public Health and Medical Subjects No. 71. Methods for the Examination of Waters and Associated Materials. London: HMSO.

ASH RJ, MAUCK B and MORGAN M (2002) Antibiotic resistance of Gram negative bacteria in rivers, United States of America. Emerg. Infect. Dis. 8 7-12.

ASHBOLT NJ (2004) Microbial contamination of drinking water and disease outcomes in developing regions. Toxicol. 198 (1-3) 229-238.

ASHIRU JO, SALAU T and ROTILU IO (1993) Incidence of Aeromonas species in diarrhoeic stool, University College Hospital, Ibadan, Nigeria. Comp. Immunol. Microbiol. Infect. Dis. 16 51-54.

ASHTON P and RAMASHA V (2002) Water and HIV/AIDS: Some strategic considerations in Southern Africa: In: Turton AR and Henwood R (eds.) Hydropolitics in the Developing World: A Southern African Perspective. African Water Issues Research Unit, Pretoria. $217-235$

ASHTON PJ (2000) The potential implication of HIV/AIDS for the Thukela Water Project. Contract Report to the Department of Water Affairs and Forestry. Report No. ENV-P-C-2000-014. Pretoria: Division of Water, Environment and Forestry Technology, CSIR. VII. 19 pp.

ASHTON PJ (2001) Avoiding conflicts over African water resources. Ambio 31 (3) 236-242.

AUVERT B (2001) HIV infection among youth in a South African mining town is associated with herpes simplex virus-2 seropositivity and sexual behaviour. AIDS 15 5885-5989.

AYOUBA A, MAUCLERE P and MARTIN PMV (2001) HIV-1 group O infection in Cameroon, 1986-1998. Emerg. Infect. Dis. 7 (3) 466-467.

BALTAZAR JC and SOLON FS (1989) Disposal of faeces of children under two years old and diarrhoea incidence: a case-control study. Int. J. Epi. 18 (Suppl.) 16-19.

BARKI Y, AMZAU S, MANNIOUI A and BENJOUD A (2001) The susceptibility of macrophages to human immunodeficiency virus type 1 X 4 isolates depends on their activation state. Biomed. Pharmacother. 55 (1) 32-38.

BLACK RE (1993) Persistent diarrhoea in children in developing countries. Pedriatr. Infect. Dis. J. 12 751-761.

BLACK RE (1993) Persistent diarrhoea in children in developing countries. Pedriatr. Infect. Dis. J. 12 751-761.

BOUYAC-BERTOIA M, DVORIN JD and FOUCHEIR RA (2001) HIV-1 infection requires a functional integrase. Mol. Cell. Biol.7 (5) $1025-1035$

BRADSHAW D, GROENEWALD P, LAUBSCHER R, NANNAN N, NOJILANA B, NORMAN R, PIETERSE D and SCHNEIDER M (2003) Initial Burden of Disease Estimates for South Africa, 2000. Cape Town: South African Medical Research Council. ISBN: 1919809-64-3. http://www.mrc.ac.za/bod/bod.htm Accessed on 02/04/03.

BRADSHAW D, JOHNSON L, SCHNNEIDER H, BOURNE D and DORRINGTON R (2002) Orphans of HIV/AIDS epidemic: The time to act is now. MRC Policy Brief. This document can be accessed at: http://www.mrc.ac.za. Accessed on 06/10/04.

BRADSHAW D, SCHNEIDER M, LAUBSCHER R and NOJILANA B (2002) Cause of death profile, South Africa 1996. Burden of Disease Research Unit Report. South African Medical Research Council. http://www.mrc.ac.za/bod/profile.pdf Accessed on 02/04/03.

BRATHWAITE AR (2001) Integrating HIV/STI prevention and care with family planning services. Concepts/Strategy Paper. Youth Now.

BREDELL H, WILLIAMSON C, SONNENBERG P, MARTIN D and MORRIS L (1998) Genetic characterization of HIV-1 from migrant workers on three South African gold mines. AIDS Res. Hum Retroviruses 14 677-684.

BUCHACZ KA, WILLIAMSON DA and KROWKA JF (1998) Genetic and immunologic host factor associated with susceptibility to HIV-1 infection. AIDS 12 (suppl A) S87-94.

BUKRINSKY MI, STANWICK TL, DEMSEY MP and STEVENSON M (1991) Quiescent T lymphocytes as an inducible virus reservoir in HIV-1 infection. Sci. 254 (5030) 423-427.
BURKE DS (1997) Recombination of HIV: An important viral evolution strategy. Emerg. Infect. Dis. 3 (3) 253-259.

CAMPBELL C and WILLIAMS B (1999) Managing disease in the goldmines: 'work-related' and 'non-work-related' diseases. S. Afr. J. Med. 88 789-795.

CARR JK, LAUKKANEN T and SALIMEN MO (1999) Characterization of subtype A HIV 1 from Africa by full genome sequence. AIDS 13 1819-1926.

CARR JK, SALIMEN MO and ALBERT J (1998) Full genome sequence of human immunodeficiency virus type 1 subtypes $\mathrm{G}$ and $\mathrm{A} / \mathrm{G}$ intersubtype recombinant. Virol. 247 22-31.

CHEN JC and ALBERT SM (2004) Browning dynamics, molecular dynamics and Monte Carlo modeling of colloidal systems. Adv. Col. Inter. Sci. 112 159-173.

CIA (2000) The World Factbook: County Listing. Washington, DC: Central Intelligence Agency of the United States of America.

CLARK DP (1999) New insights into human cryptosporidiosis. Clin. Microbiol. Rev. 12 (4) 554-563.

COHEN DE and WALKER BD (2001) Human Immunodeficiency Virus pathogenesis and prospects for immune control in patients with established infection. Clin. Infect Dis. 32 (12) 1756-1768.

COKER AO and ADEFOSO AO (1994) The changing patterns of Campylobacter jejuni/coli in Lagos, Nigeria after ten years. E. Afr. Med J. 71 437-440.

COKER AO, ISOKPEBI RD, THOMAS BN, AMISU $\mathrm{K}$ and OBI CL (2002) Human campylobacteriosis in developing countries. Emerg. Infect. Dis. 8 (3) 237-243.

COLVIN M, ABDOOL KARIM SS, CONNOLLY C, HOOSEN AA and NTULI N (1998) HIV infection and asymptomatic sexually transmitted diseases in a rural South African community. Intl $J$. $S T D \& A I D S 9548-550$

CORBERT SS, MULLER-TRUTWIN M and VERMISSE P (2000) Env sequence of simian immunodeficiency virus from chimpanzees in Cameroon are strongly related to those of human immunodeficiency virus group $\mathrm{N}$ from the same geographical area. J. Virol. 74 (1) $529-534$

CORRY JEL and ATABAYHI (2001) Classical and molecular identification of thermotolerant campylobacters from poultry meat. J. Appl. Microbiol. 90 96S-114S.

COSTA LJ, MUNERATO P, DIAZ RS and TANURI A (2000) Generation of intersubtype human immunodeficiency virus type-1 recombinants in vitro: Influences in the biological behaviour and establishment of productive infection. Virol. 268 440-451.

CREWE M (2000) South Africa: Touched by the vengeance of AIDS. S. Afr. J. Int. Affairs 7 (2) 23-38.

CULLEN BR (2001) A new entry route for HIV. Nature Medicine 7 (1) 20-21.

CURTIS V and CAIRNCROSS S (2000) Domestic hygiene and diarrhoea - pinpointing the problem. Trop. Med. Int. Hlt 5 (1) 22-32.

DANIELS DL, COUSENS SN, MAKOAE LN and FEACHEM RG (1990) A case-control study of the impact of improved sanitation on diarrhoea morbidity in Lesotho. Bul. WHO 68 455-463.

DE RODA-HUSMAN AM, BLACK H, BROUWER and SCHUITEMAKER H (1999) CC chemokine receptor 5 cell-surface expression in relation to $\mathrm{CC}$ chemokine receptor 5 genotype and the clinical cause of HIV infection. J. Immunol. 168 (8) 4597-4603.

DEACON NJ, TSYKIN A, SOLOMON A and SMITH K (1995) Genomic structure of an attenuated quasi species of HIV-1 from a blood transfusion donor and recipient. Sci. 270 988-991.

DEORA A and RATNER L (2001) Viral protein u (vpu)-mediated enhancement of human immunodeficiency virus type 1 particle release depends on the rate of cellular proliferation. J. Virol. 75 (14) 6714-6718

DEPARTMENT OF HEALTH (DoH) (1999) Ninth National HIV Seroprevalence Survey Of Women Attending Antenatal Clinics in South Africa in 1998.

DEPARTMENT OF HEALTH (DoH) (2000) National HIV Sero-prevalence Survey Of Women Attending Public Antenatal Clinics in South Africa. Directorate: Health Systems Research and Epidemiology, Department of Health, Pretoria.

DEPARTMENT OF HEALTH (DoH) (2003) Operational plan for comprehensive HIV and AIDS care, management and treatment for South 
Africa. Full Report. Online at: http://www.gov.za/reports/2003/aidsplanchap16.pdf Accessed on 10/03/04.

DEPARTMENT OF HEALTH (DoH) (2002) Annual Report. Department of Health. Pretoria. Accessed online at: http://www.doh.gov. za/docs/annrep-f.htm on 10/03/04.

DORRINGTON R, BOURNE D, BRADSHAW D, LAUBSCHER R and TIMAEUS IM (2001) The impact of HIV/AIDS on adult mortality in South Africa. MRC Technical Report ISBN 1-919809-14-7 Online at: www.mrc.ac.za/bod Accessed on 10/10/03.

DORRINGTON RE, BRADSHAW D and BUDLENDER D (2002) HIV/AIDS profile of the provinces of South Africa- indicators for 2002. Center for Actuarial Research, Medical Research Council and the Actuarial Society of South Africa.

DUNNE E, ANGORAN-BENIE H, KAMELAN-TANO A, SIBAILLY T, MONGA B, KONADIO L, ROEDS T, WIKTOR S, LACKRITZ E, MINTZ E and LUBY S (2001) Is drinking water in Abidjan, Cote d' Ivoire safe for infant formula? J. Acquired Immu. Def. Syndr. $\mathbf{2 8}$ (4) 393-398.

DYER WB, GECZY AF and KENT SJ (1997) Lympho-proliferative immune function in the Sydney Blood Bank Cohort, infected with natural nef/long terminal repeat mutant and in other long-term survivors of transfusion-acquired HIV-1 infection. AIDS 11 (13) 1565-1574.

EL-SHEIKH SM and EL-ASSOULI SM (2001) Prevalence of viral, bacterial and parasitic enteropathogens among young children with acute diarrhea in Jeddah, Saudi-Arabia. J. Health Popul.Nutr. 19 25-30.

ENABOR B (1998) Integrated water management by urban poor women: A Nigerian slum experience. J. Wat. Res. Dev. 14 (14) 505-512.

ENGELBRECHT JFP (1998) Groundwater pollution from cemeteries In: Proc. of the Water Institute of South Africa, Biennial Conference. Volume 1. Cape Town, 4-7 May.

FAO (2000) Aquastat Information Services On Water In Agriculture And Rural Development. Rome: Food and Agriculture Organization of the United Nations.

FACKLER OT, D'ALOJA P, BAUR AS, FEDERICO $\mathrm{M}$ and PETERLIN BM (2001) Nef from human immunodeficiency virus type 1 (F12) inhibits viral production and infectivity. J. Virol. 75 (14) 66016608 .

FIELD-NUGER ML and NYBLADE L (2001) Community involvement in the prevention of mother-to-child-transmission of HIV: Insights and Recommendation. International Center for Research on Women Publications. Accessed online at: http://www.icrw.org docs/mtct 2001.pdf on 04/03/04.

FLAMAND L, CROWLEY RW and LUSSSO P (1998) Activation of CD8 T lymphocytes through the T cell receptor turns on CD4 gene expression: implications for HIV pathogenesis. Proc. Natl. Acad. Sci. USA 95 2111-3116.

FOSTER JL, MOLINA RP and LUO (2001) Genetic and functional diversity of human immunodeficiency virus type 1 subtype B nef primary isolate. J. Virol. 75 (4) 1672-1680.

GERMANI Y, MINSSART P, VIHITO M, YASSIBANDA S, HLAZION P and HOCQUET D (1998) Etiologies of acute, persistent and dysenteric diarrhoeas in adults in Bangui, Central African Republic in relation to HIV serostatus. Am. J. Trop. Med. Hyg. 59 1008-1014.

GLEICK PH (1999) The World's Water 1998-1999: The Biennial Report on Fresh Water Resources. Washington, DC: Island Press. 308 pp.

GLYNN JR (2001) Why do young women have a much higher prevalence of HIV than young men? A study in Kisumu, Kenya and Ndola, Zambia. AIDS 15 (4) S51-60.

GOA F, ROBERTSON DL and CARRUTHERS CD (1996) The heterosexual human immunodeficiency virus type 1 in Thailand is caused by an intersubtype (A/E) recombinant of African origin. J. Virol. 70 7013-7029.

HANN BH, SAHW GM, DE COCK KM and SHARP PM (2000) AIDS as a zoonosis: Scientific and public health implications. Sci. 287 (5453) 607-614.

HANNINEN ML (1993) Occurrence of Aeromonas spp. in samples of ground meat and chicken. Int. J. Food Microbiol. 18 (4) 339-342.

HANNINEN ML (1994) Phenotypic characteristics of the three hybridisation groups of Aeromonas hydrophilia isolated from different sources. J. Appl. Bacteriol. 76 455-464.
HAVELAAR AH, SCHETS, FM, VAN SILFOUT A, JANSEN WH, WIETEN G and VAN DER KOOIJ D (1992) Typing of Aeromonas strains from patients with diarrhoea and from drinking water. J. Appl. Bacteriol. 72 435-444.

HAVELAAR AH, VERSTEEGH JF and DURING M (1990) The presence of Aeromonas in drinking water supplies in The Netherlands. Zentralbl. Hyg. Unweltmed. 190 236-256.

HENDEL H, CIALLAT-ZUCMAN S and LEBUACNEC (1999) New class I and II alleles strongly associated with opposite patterns of progression of AIDS. J. Immunol. 162 (11) 6942-6947.

HEYWOOD M (1999) SADC's policy framework on AIDS and employment: Too little too late? AIDS Anal. Afr. 9 (6) 12-13.

HILBORN, ED, MSHAR PA, FIORENTINO TR, DEMBEK ZF, BARRETT TJ, HOWARD RT and CARTTER ML (2000) An outbreak of Escherichia coli $\mathrm{O} 157: \mathrm{H} 7$ infections and haemolytic uraemic syndrome associated with consumption of unpasteurized apple cider. Epidemiol. Infect. 124 31-36.

HOGE CW, GAMBEL JM, SRIJAN A, PITARANGSIC C and ECHEVERIA P (1998) Trends in antibiotic resistance amongst diarrhoeal pathogens isolated in Thailand over 15 years. Clin. Infect. Dis. 26 341-345.

HU DJ, TIMOTHY J and DONDERON TJ (1996) The emerging genetic diversity of HIV: The importance of global surveillance for diagnostic, research and prevention. J. Am. Med. Assoc. 275 (3) 210-216.

HUMAN SCIENCES RESEARCH COUNCIL (HSRC) (2002) Nelson Mandela/HSRC Study of HIV/AIDS. ISBN 0-7069-2007-9.

IAVI (1999) South Africa's explosive AIDS epidemic. Accessed online at: www.iavi.org

IRC (2004) What have we learned. Available at http://wwwirc.nl/ page/3500 accessed on 10/03/05.

JANOFF EN and SMITH PD (1998) Prospectives on gastrointestinal infections in AIDS. AIDS 17 451-463.

LASTOVICA AJ, MITCHNE C and MAARTENS G (2001) Campylobacter infection in HIV positive South African children and adults. In: Hacker J (ed.) Proc. Abstracts of Scientific Presentations of the $11^{\text {th }}$ Int. Workshop on Campylobacter, Helicobacter and Related Organisms. Freiburg, Germany. Sept 1-5, 2001. Intl. J. Med. Microbiol. 291 (Suppl 31) 151.

JET AE, YU H and KARLMANN GJ (2000) High rate of recombination throughout the human immunodeficiency virus type 1 genome. J. Virol. 74 (3) 1234-1240.

JOCHELSON K, MOTHIBELI M and LEGER JP (1991) Human immunodeficiency virus and migrant labour in South Africa. Intl J. Health Serv. 21 157-173.

JOSSINET F, PAILLART JC and WESTHOF E (1999) Dimerization of HIV-1 genome RNA subtypes A and B : RNA loop structure and magnesium binding. RNA 5 (9) 1222-1234.

KAMMINGA E and WEGELIN-SCHURINGA (2003) HIV/AIDS and water, sanitation and hygiene. In: HIV/AIDS and Water, Sanitation and Hygiene. Thematic Overview Paper-IRC International Water and Sanitation Centre.

KARIM QA (2000) Trends in HIV infection: Beyond current statistics. S. Afr. J. Intl. Aff. 7 (2) 1-21.

KASLOW RA, CARRINGTON M and APPLE R (1996) Influence of combination of human major histocompactibility complex gene on the course of HIV-1 infection. Nat. Med. 2 (4) 405-411.

KIROV SM, HUDSON JA, HAYWARD LJ and MOTT SJ (1994) Distribution of Aeromonas hydrophila hybridisation groups and their virulence properties in Australian clinical and environmental strains. Lett. Appl. Microbiol. 18 71-73.

KLEINER SM (1999) Water: An essential but overlooked nutrient. $J$. Am. Diet. Ass. 99 (2) 200-206.

KOSTRIKIS LG and BAGDAGES E and CAO Y (1995) Genetic analysis of human immunodeficiency virus type 1 strains from patients in Cyprus: Identification of a new subtype designated I: J. Virol. 71 7088-7091.

KUWATA T, MIYAZAKI Y and IGARASHI T (1997) The rapid spread of recombination during a natural in vitro infection with two human immunodeficiency type 1 strains. J. Virol. 71 7088-7091.

LAMA J and TRONO D (1998) Human immunodeficiency virus type-1 protein interacts with cellular protein HO3. J. Virol. 72 (2) 16711676. 
LEMPICKI RA, KOVACS JA and BASELER MW (2000) Impact of HIV-1 infection and highly active antiretroviral therapy on kinetics of CD4 and CD8 T-cell turnover in HIV infected patients Proc. Natl. Acad. Sci. USA 97(25) 13778-13783.

LEVINE WC, BUEHLER JW, BEAN NH and TAUXE RV (1991) Epidemiology of nontyphoidal Salmonella bacteremia during the human immunodeficiency virus epidemic. J. Infect. Dis. 164 81-87.

LJUNGSTROM I and CASTOR B (1992) Immune response to Giardia lambia in waterborne outbreak of giardiasis in Sweden. J. Med Microbiol. 36 347-352.

LOWENSON J and WHITESIDE A (1997) Social and economic issues on HIV/AIDS in Southern Africa: a review of current research. SAFAIDS 45-46.

LULE J, MERMIN J, MALAMBA S, COUTINHO A, KIZITO F, NAKANJAKO D, EKWAU P, WAISWA B, RANSOM R and QUICK R (2005) The impact of a safe water system on household water quality and diarrhoea among person with and without HIV in rural Uganda. Centers for Disease Control and Prevention. Am. J. Trop. Med. Hyg. 73 (5) 926-933.

LURIE M (2000) Migration and AIDS in Southern Africa: A review. S. Afr. J. Sci. 96 (6) 343-347.

LYLES RH, MUNOZ A, YAMASHIKA TE, BAZMI H, DETELS R, RINALDO CR, MARGOLICK JB PHAIR JP and MELLORS JW (2000) Natural history of human immunodeficiency virus type 1 viraemia after seroconversion and proximal to AIDS in large cohorts of homosexual men. Multicentre AIDS Cohort Study. J. Infect. Dis. 181 (3) 872-880.

MACPHAIL C (2002) Relative risk of HIV infection among young men and women in a South African township. Int. J. STD \& AIDS 13 331-342.

MARGOTTI F, BOUR SP, DURAND H and SELIG G (1998) A novel human WB protein h-beta TrCp, that interacts with HIV-1 vpu connects CD4 to ER degradation pathway through F-box motive. Mol. Cell. Biol. 1 (4) 565-574.

MARODON G, WARREN D, FILOMIO MC and POSNETH DN (1999) Productive infection of double negative T cells with HIV in vivo. Proc. Natl. Acad. Sci. USA 96 (21) 11958-11963.

McCOY D, BESSER M, VISSER R and DOHERTY T (2002) Interim findings on the national PMTCT pilot sites. Health Systems Trust. ISBN: 1-919743-64-2.

MERTENS TE, JAFFAR S, FERNANDO MA, COUSENS SN and FEACHEM RG (1992) Excreta disposal and latrine ownership in relation to childhood diarrhoea in Sri Lanka. Int. J. Epi. 21 11571164.

MICHAEL NL, CHANG G, LOUIE LG, MASCOLA JR, DOUDERO D, BIRX DL and SHEPPARD HW (1997) The role of viral phenotype and CCR5 gene defects in HIV - 1 transmission and disease progression. Nat. Med 3 (3) 338-340.

MICHEL NL (1999) Host genetic influences in HIV-1 pathogenesis. Curr. Opin. Immunol. 11 466-474.

MOMBA MNB and KALENI P (2002) Regrowth and survival of indicator microorganisms on the surfaces of household containers used for the storage of drinking water in rural communities of South Africa. Water Res. 36 3023-3028.

MOMBA MNB and NOTSHE TL (2003) The microbiological quality of ground-water derived drinking water after long storage in household containers in a rural community of South Africa.

MOMBA MNB, CLOETE TE, VENTER SN and KFIR R (2000) Influence of disinfection processes on the microbial quality of potable groundwater in a laboratory-scale system model. J. Water SRT Aqua 49 (2000) 23-33

MOMBA MNB, MAKALA N, TYAFA $Z$ and BROUCKAERT BM (2004) Ensuring Sustainable Effective Disinfection In Small Rural Municipal Water Treatment Plant. WRC Report K5/1391. Water Research Commission, Pretoria.

MORRIS CN and CHEEVERS EJ (2000) The direct cost of HIV/AIDS in a South African sugar mill. AIDS Analysis Afr. 10 (5) 7-8.

MORRIS L, WILLIAMSON C, GRAY C and TIEMESSEN C (2000) HIV-1 subtype $\mathrm{C}$ as a major determinant of global AIDS epidemic. S. Afr. J. Sci. 96 (6) 339-342.

MORRIS L, CILLIERS T and BREDELL H (2001) CCR5 is a major coreceptor used by HIV-1 subtype $\mathrm{C}$ isolates from patients with active tuberculosis. AIDS Res. Hum. Retrov. 17 (8) 697-701.

MUSEY L, HUGHES J and SCHACKER T (1997) Cytotoxic T-cell responses, viral load and disease progression in early immunodeficiency virus type-1 infection. New Engl. J. Med. 337(18) 12671274.

MUYIMA NYO and NGCAKANI F (1998) Indicator bacteria and regrowth potential of the drinking water in Alice, Eastern Cape. Water SA 24 (1) 29-34.

NASIOULAS G, PARASKOVIS D, MARGIORKINIS E (1999) Molecular analysis of the full length genome of HIV type 1 subtype I: Evidence of A/G/I recombination. AIDS Res.Hum. Retrov. 15 745-758.

NATH KJ (2003) Home hygiene and environmental sanitation: a country situation analysis for India. Int. J. Environ Hlt Res. 13 (1) 19-28.

OBI CL AND BESSONG PO (2002) Diarrhoeagenic bacterial pathogens in HIV positive patients with diarrhea in rural communities of Limpopo Province, South Africa. J. Health Popul. Nutr. 20 (3) 230-234.

OBI CL, COKER AO, EPOKE J and NDIP RN (1997) Enteric bacterial pathogens in stools of residents of urban and rural regions in Nigeria: A comparison of patients with diarrhoea and controls without diarrhoea. J. Diarr. Dis. Res. 15 (4) 241-247.

OBI CL, COKER AO, EPOKE J and NDIP RN (1998) Distributional patterns of bacterial diarrhoeagenic agents and antibiograms of isolates from diarrhoand non-diarrhoeic patients in urban and rural areas of Nigeria. Cent. Afr. J. Med. 44 (9) 223-229.

OBI CL, MCADOO HP, MURRAY M, TSWANA SA and MOYO SR (1997) HIV infection and HIV-1 clades among pregnant women in Harare, Zimbabwe. Cent. Afr. J. Med. 43 (7) 188-192.

OBI CL, MCADOO HP and ONIGBINDE AO (1997) Subtypes of HIV1 and the impact of dual infection of HIV-1 and measles virus on micronutrient levels of pregnant women in Harare, Zimbabwe. Cent. Afr. J. Med. 43 (6) 165-172.

OBI CL, ONI SA, OKORIE A, THABEDE D, BESSONG PO and JORDAAN A (2002) HIV seroprevalence in rural Bela Bela and Tshakhuma-Thohoyandou areas of South Africa. Proc. Abstract XIV Int. AIDS Conf. Barcelona, Spain, July 7-14.

OBI CL, POTGIETER N, BESSONG PO, IGUMBOR EO and GREEN E (2003) Prevalence of pathogenic bacteria and retroviruses in the stools of patients presenting with diarrhoea from rural communities in Venda, South Africa. S. Afr. J. Sci. 99 589-591.

OBI CL, POTGIETER N, BESSONG PO and MATSAUNG G (2003) Scope of potential bacterial agents of diarrhea and microbial assessment of quality of river water sources in rural Venda communities in South Africa. Water Sci. Technol. 47 (3) 59-64.

OBI CL, POTGIETER N, BESSONG PO, IGUMBOR EO and GREEN E (2004) Gene encoding virulence makers among Escherichia coli isolates from diarrhoeic stools samples and river sources in rural Venda communities of South Africa. Water SA 30 (1) 37-42.

PALLET J (1997) Sharing Water in Southern Africa. Windhoek. Desert Research Foundation of Namibia. 121 pp.

PAXTON WA, LIU R and KANG S (1998) Reduced HIV-1 infectibility of HIV-1 lymphocytes from exposed uninfected individual: association with low expression of CCR5 and high production of betachemokines. Virol. 244 (1) 66-73.

PELLEGRIN I, LEGRAND E and NEAU D (1996) Kinetics of appearance of neutralizing antibodies in 12 patients with primary or recent HIV-1 infection and relationship with plasma and cellular viral loads. J. Acqr. Immu. Def. Syndr. Hum. Retrovirol. 11 (5) 438-447.

PIOT P (2003) AIDS: The Need for an Exceptional Response to an Unprecedented Crisis. Presidential Fellows Lecture, 20 November 2003, World Bank.

POIGNARD P, SAPHIRE EO, PARREN PW and BURTON DR (2001) Gp 120: Biologic aspects of structural features. Ann. Rev. Immunol. 19 253-274.

PRASAD KN, NAG VL, DHOLE TN and AYYAGARI A (2000) Identification of enteric pathogens in HIV positive patients with diarrhea in Northern India. J. Health Popul. Nutr. 18 23-26.

QUINN TC (1997) Diversity of Campylobacter species and its impact on patients infected with human immunodeficiency virus. Emerg. Infect. Dis. 24 1114-1117.

RAHAMAN H, RAHAMAN MM, WOJTYNIAK B and AZIZ KM (1985) Impact of environmental sanitation and crowding on infant 
mortality in rural Bangladesh. Lancet 2 (8445) 28-31.

RAWAT KP, SHARMA AK and RAO SM (1998) Microbiological and physico-chemical analysis of radiation disinfected municipal sewage. Water Res. 32 737-740.

REYNES J, PORTALES P and SEGONDAY M (2000) CD4+ T-cell surface CCR5 as a determining factor of virus load in persons infected with HIV type-1. J. Infect. Dis. 181 (3) 927-932.

RHODES DI, ASHTON L and SOLOMON A (2000) Characterisation of three nef defective immunodeficiency virus type 1 strains associated with long term non-progression: Australian long term non-progressors study group. J. Virol. 74 (22) 10581-10588.

ROBERTSON LJ and GJERDE B (2000) Isolation and enumeration of Giardia cyst, Cryptosporadium oocyst and Ascaris eggs from fruits and Vegetables. J. Food Product. 63 775-778.

ROBEY WG, SAFAI B, OROSZLAN S, ARTHUR LO, GONDA MA, GALLO RC and FISCHINGER PJ (1985) Characterization of envelope and core structured gene products of HTLV-III with sera from HIV patients. Sci. 228 (4699) 593-595.

ROQUES P, MENU E and NARWA R (1999) An unusual HIV Type 1 env sequence embedded in a mosaic virus from Cameroon: Identification of a new clade. European Network on the study of in-utero transmission of HIV-1. AIDS Res. Hum. Retrov. 15 (17) 1585-1589.

ROSENBERG ES, ALTFELD M, POON SH, PHILLIPS MN, WIKES BM, ELDRIDGE RL, ROBBINS GK, D' AQUILA RT, GOULDER PJ and WALKER BD (2000) Immune control of HIV - 1 after early treatment of acute infection. Nat. 407 (6803) 523-526

SADC (1995) Protocol on shared watercourse systems in Southern African Development Community (SADC) region. Gaborone: SADC Secretariat.

SADC (2000) SADC review and country profiles. Gaborone: SADC Secretariat. Available at www.sadcreview.com/country\%20profile s\%202000

SAHA K, ZHANG J and GUPTA A (2001) Isolation of primary HIV 1 that target CD8 T lymphocytes using CD8 receptor. Nat. Med. 7 (1) $65-71$

SAHLSTROM L, ASPAN A, BAGGE E, DANIELSON NL and AHBILNA A (1994) Bacterial pathogen incidences in sludge from Swedish sewage treatment plants. Water Res. 38 1989-1994.

SALIMEN MO, CARR JK and ROBERTSON DL (1997) Evolution and probable intersubtype recombinant human immunodeficiency virus type 1 in a Zambian couple. J. Virol. 71 (4) 2647-2655.

SCHACKER T LITTLE S, CONNICK E, GEBHARD-MITCHELL K, ZHANG ZO and KRIEGER J (2000) Rapid accumulation of human immunodeficiency virus (HIV) in lymphatic tissue reservoirs during acute and early HIV-infections: implications for timing of antiretroviral therapy. J. Infect. Dis. 181 (1) 354-357.

SCHAEFFER E, GLEZIUNAS R and GREENE WC (2001) Human immunodeficiency virus type 1 nef function at the level of virus entry by enhancing cytoplasmic delivery of the virion. J. Virol. $\mathbf{7 5}$ (6) 2993-3000.

SCHANKER T, LITTLE S and CONNICK E (2000) Rapid accumulation of human immunodeficiency virus in lymphatic tissue reservoir during acute and early HIV infection: implications for timing antiretroviral therapy. J. Infect. Dis. 181 (1) 354-357.

SCHUTTEN M, VAN BAALEN CA, GUILLON C, HUISMAN RC, BOERS PHM, SINTNICOLAAS K, GRUTERS RA and OSTERHAUS ADME (2001) Macrophage Tropism of Human Immunodeficiency Virus Type 1 Facilitates In Vivo Escape from Cytotoxic TLymphocyte Pressure. J. Virol. 75(6) 2706-2709.

SIMON F, MAUCLERE P, ROQUES P, LOUSSERT-AJAKA I, MULLER-TRUTWIN M, SARAGOSTI S, GEORGES-COURBOT MC, BARRE-SINOUSSI F and BRUN-VEZINET F (1998) Identification of a new human immunodeficiency virus type 1 distinct from group M and O. Nat. Med. 4 (9) 1032-1037.

SMART R (2000) Children living with HIV/AIDS in South Africa: A rapid appraisal. Pretoria: Save the Children (UK).

SMART R (2003) Policies for Orphans and Vulnerable Children: A Framework for Moving Ahead. Policy ISBN: 0-960 5196-4-5.

SOUTH AFRICAN DEMOGRAPHIC HEALTH SURVEY (SADHS) PROJECT TEAM (1999) South Africa in Transition: Selected Findings from the South African Demographic Health Survey 1998. Government Printers, Pretoria.
SOVA P, VOLSKY DJ, WARY L and CHAO W (2001) Vif is largely absent from human immunodeficiency virus type-1 mature virions and associate mainly with viral particles containing unprocessed gag. J. Virol. 75 (12) 5504-5517.

SPERBER SJ and SCHLEUPNER CJ (1987) Salmonellosis during infection with human immunodeficiency virus. Rev. Infect. Dis. 9 925-934.

STANTON BF and CLEMENS JD (1987) An educational intervention for altering water sanitation behaviours to reduce childhood diarrhoea in urban Bangladesh. A randomised trial to access the impact of the intervention on hygienic behaviours and rate of diarrhoea. Am. J. Epi. 125 292-301.

TAKEHISA J, ZEKENG L and IDO E (1999) Human immunodeficiency virus type 1 intergroup $(\mathrm{M} / \mathrm{O})$ recombination in Cameroon. J. Virol. 73 (8) 6810-6820.

THEILLEUX-DELANDE V, GIRARD F, HUYNH-DINH T, LANCELOT G and POALETTIJ (2000) The HIV - 1 (Lai) RNA dimerization. Thermodynamic parameters associated with the transition from jissing complex to the extended dimer. Euro. J. Biochem. 267 (9) 2711-2719

UNAIDS (2000) Epidemiological Fact Sheet on HIV/AIDS and Country Profiles. Geneva: UNAIDS/WHO. Also available at: www.unaids. org/countryprofiles. Accessed online on 29/12/2003.

UNAIDS (2000) Report on the Global HIV/AIDS Epidemic. Geneva: UNAIDS, $136 \mathrm{pp}$.

UNAIDS (2002) Report on the Global HIV/AIDS Epidemic. Geneva, UNAIDS.

UNAIDS (2003) AIDS Epidemic Update: December 2003. Geneva UNAIDS/World Health Organisation. www.unaids.org/AIDSE biUpdate2003 en.pdf. Accessed online on 29/12/2003.

UNFPA (2002) The State of World Population 2002. UNFPA Publications. http://www.unfpa.org/swp/swpmain.htm Accessed online on $12 / 02 / 04$.

UNICEF (2003) Children on the Brink 2002: A joint report on orphan estimates and program strategies. http://www.unicef.org. Accessed online on $12 / 02 / 04$.

UNICEF: Prevention of parent to child transmission of HIV/AIDS www.unicef.org/aids/index preventionMTCT.html 2004. Accessed online on $12 / 02 / 04$.

UNICEF: UNICEF statistics: Water Www.chilinfo.org/water2003. Accessed online on 25/06/04.

UNITED NATION (1995) World population prospects. United Nations Publications. New York. www.un.org/wpp.htm Accessed online on $12 / 02 / 04$.

US CENSUS BUREAU (2002) Population Statistics. US Census Bureau. http://www.census.gov/statab/www Accessed online on 12/02/04.

US MISSION TO SOUTH AFRICA (2003) Inter-agency PEPFAR Annual Program Statement US government mission to South Africa. http://southafrica.usembassy.gov/www.haids.htm Accessed online on $4 / 03 / 04$.

USAID (2002) USAID's expanded response to HIV/AIDS. USAID.

VAN HARMELEN JH (1999) A predominantly HIV type 1 subtype Crestricted epidemic in South African urban populations. AIDS Res. Hum. Retro. 15 395-398.

VERONESE FD, DEVICO AL, COPELAND TD, OROSZLAN S, GALLO RC and SARNGADHARAN MG (1985) Characterization of gp41 as a trans-membrane protein coded by the HTLV-III/LAV envelope gene. Sci. 229 (4720) 1402-1405.

WALLI R, REINHART B, LUCKOW B, LEDERER E, LOCH O and MALO A (1998) HIV - 1 infected long term slow progressing heterozygous for delta 32-CCR5 show significant lower plasma viral load than wild type slow progressors. J. Acq. Immune Def. Synd. Hum. Retrovirol. 18 (3) 229-233.

WATER RESEARCH COMMISSION (WRC) (1998) Quality of Domestic Water Supplies. Volume 1: Assessment Guide. WRC Report No TT 101/98. Water Research Commission, Department of Water Affairs and Forestry and Department of Health, South Africa.

WEINBERG ZG, ASHBELL G, CHEN Y, GAMBURG M and SELA S (2004) The effect of sewage irrigation on safety and hygiene of forage crops and silage. Animal Feed Sci. Technol. 116 271-280.

WHITE DG, PIDDOCK LJV, MAURER JJ, ZHAO S, RICCI V and THAYER SG (2000) Characterization of fluoroquinolone resistance 
among veterinary isolates of avian Escherichia coli. J. Antimicr. Ag. Chemother. 44 (10) 2897-2899.

WHITESIDE AW (1999) The AIDS epidemic in SADC. AIDS Anal. Afr. 10 (2) 11

WHITESIDE AW and SUNTER C (2000) AIDS: The Challenge for South Africa. Cape Town: Human and Rosseau/Tafelberg. 179 pp.

WHO (2002) Aeromonas. In: Guidelines for Drinking-water Quality ( $2^{\text {nd }}$ edn.). Addendum: Microbiological Agents in Drinking-Water. World Health Organization, Geneva. 1-13.

WHO (2003) Emerging Issues in Water and Infectious Disease. World Health Organization, Geneva.

WHO (2004) Water sanitation and hygiene. Links to health facts and figures. Available at http://www.who.int/water_sanitation_health/ en/factsfigures04.pdf. Accessed on 23 June 2006.

WILLARD-GALLO KE, FUITADO M, BURNY A and WOLINSKY SM (2001) Down modulation of TCR/CD3 surface complexes after HIV-1 infection is associated with differential expression of the viral regulatory gene. Eur. J. Immunol. 31 (4) 969-979.

WILLI R, REINHART B and LUCKOW B (1998) HIV-1 infected long term slow progressors heterozygous for delta 32-CCR5 show significant lower plasma viral load than wild type slow progressors. J. Acqr. Immu. Def. Syndr. Hum. Reterovirol. 18 (3) 229-233.

WILLIAMS BG, MACPHAIL C, CAMPBELL C, TALJAARD D, GOUWS E, MOEMA S, MZAIDUME Z and RASEGO B (2000) The Carletonville-Mothusimpilo project: limiting transmission of HIV through community-based interventions. S. Afr. J. Sc. 96 351-359.

WILLIAMS BG, GOUWNS E, COLVIN M, SITAS F, RAMJEE G and KARIM SSA (2000) Patterns of infection: Using age prevalence data to understand the epidemic of HIV in South Africa. S. Afr. J. Sci. 96 (6) 305-312.
WONG HC, LIU C, PAN T, WANG K, LEE C and SHIH D (1999) Molecular typing of Vibrio parahaemolyticus isolates, obtained from patients involved in food poisoning outbreaks in Taiwan, by random amplified polymorphic DNA analysis. J. Clin. Microbiol. 37 (06) 1809-1812.

WORLD BANK (1998) World Development Indicators 1998. Washington DC: World Bank. 390 pp.

WORLD BANK (1999) Intensification of Action against HIV/AIDS in Africa: Responding to a Development Crisis. Washington DC: World Bank. 90 pp.

WORLD BANK (2001) World Bank HIV/AIDS activities. Washington DC: World Bank. Available at: www.worldbank.org/html/extdr/pb/ pbaidsactivities.htm

WRI (2000) World Resources 2000-2001. Washington, DC: World Resources Institute.

ZHANG Z, SCHULER T, ZUPANIC M, WEITGREFE S, STASKUS KA, REIMANN KA, REINHARD TA and ROGAN M (1999) Sexual transmission and propagation of SIV and HIV in resting and activated CD4+ T cells. Sci. 286 (5443) 1353-1357.

ZHANGA X, MINEARA RA, GUOB Y, HWANGB CJ, BARRETT SE, IKEDAC K, SHIMIZU K and MATSUI S (2004) An electrospray ionization-tandem mass spectrometry method for identifying chlorinated drinking water disinfection byproducts. Water Res. 38 (2004) 3920-3930.

ZHOU J and AIKEN C (2001) Nef enhances human immunodeficiency virus type 1 infectivity resulting from intervirion fusion: evidence supporting a role for nef at the virion envelop. J. Virol. 75 (13) 58515859.

ZHU T, WAANG N and CARR A (1995) Evidence for coinfection by multiple strains of human immunodeficiency virus type 1 subtype $B$ in an acute seroconverter. J. Virol. 69 1324-1327. 